\title{
Challenging the
}

\section{Environmental History of}

\section{the Cerrado: Science,}

\section{Biodiversity and Politics}

on the Brazilian

\section{Agricultural Frontier}

Sandro Dutra e Silva ${ }^{1}$

\begin{abstract}
This article presents an overview of the environmental history of the Brazilian Cerrado, its environmental characteristics and the processes related to the historical change in the landscapes of this endangered ecosystem. It highlights competing classifications of the Cerrado, the role of politics in establishing them, and the environmental consequences of such classifications. More than just describing an environment, classifying an ecosystem is a political process that involves complex socioenvironmental interactions. The sources used points out the different attempts to get to know and "conquered" the Cerrado, bringing together interdisciplinary perspectives from a variety of actors and institutions. Historiographic challenges go beyond environmental descriptions in that the socioenvironmental interactions that made up this unique ecosystem are equally complex. This paper's conclusions reinforce the interdisciplinary role of environmental history in the study of ecosystems and the complex relationship between culture and nature.
\end{abstract}

Keywords: Cerrado, Environmental History, Agricultural Frontier

${ }^{1} \mathrm{PhD}$ in History, University of Brasilia, Brazil. Professor of History, Universidade Estadual de Goiás, and Centro Universitário de Anápolis, Brazil. ORCID: https://orcid.org/0000-0002-0001-5726. sandrodutr@hotmail.com 


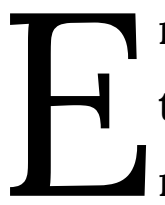
nvironmental historians have confronted enormous challenges in dealing with the relationships between natural environments and scientific inquiry. Every natural environment is full of nuances and intrinsic influences that require a careful and critical gaze at nature itself all within the frameworks of the humanities. Researchers dealing with social phenomena are cautioned to analyze their confusion without fetishizing suffering ${ }^{2}$. This challenge becomes even more intense when human perplexities are associated with socio-environmental environments. Each and every environment is complex, full of intricacies that challenge our ability to understand it. This reasoning calls attention to the ways that environmental historians are dealing with such challenges. This is not a new question, quite the opposite. It has been debated consistently since the birth of environmental history as a historiographic field. Furthermore, Donald Worster has warned us that the "ecological approach cannot alone address all the issues that historians today want addressed. It may, however, redirect their attention to some issues they have forgotten, or never been aware of ${ }^{\prime 3}$. This advice stands true today, more so than ever.

Worster has also warned us of another major challenge which the complete destruction of ecosystems and their connections to human cultures has occurred in the Western world for nearly four centuries. Moreover, in the $19^{\text {th }}$ and $20^{\text {th }}$ centuries this ecological achievement became planetary. Worster affirms that environmental historians are already aware of this reality, as what he described as an "invasion". His advice is to explore effusively all the angles of this revolution, which transformed, dramatically, the human relationship with the earth ${ }^{4}$. The historical challenges in dealing with every ecological approach are absolutely imperative. Consequently, the challenges of describing the historical development of Brazilian Cerrado has led me to ponder these questions. In this article I discuss a series of challenges faced by environmental historians when dealing with a complex and nuanced territory such as the Cerrado, a vast biome of tropical savanna in South America.

\footnotetext{
2 Boaventura de Sousa Santos, Pela Mão de Alice: O Social e o Político Na Pós-Modermidade (São Paulo: Cortez, 2013).

3 Donald Worster, "History as Natural History: An Essay on Theory and Method," Pacific Historical Review 53, no. 1 (February 1984): p.9, https://doi.org/10.2307/3639376.

4 Donald Worster, "World without Borders: The Internationalizing of Environmental History," Environmental Review: ER 6, no. 2 (1982): 8-13, https://doi.org/10.2307/3984152.
} 
Biologists consider the Cerrado the most biodiverse tropical savanna on the planet, as well as one of its most threatened ecosystems. Comprised of diverse physiognomies and floristic compositions, the Cerrado stretches across two million $\mathrm{km}^{2}$, forming a complex ecological mosaic of botanical formations like grasslands, prairies, bushed fields, tropical forest, among others. The term "savanna" falls short of the representation of the vegetative scope of the Cerrado, and therefore, its use does not express the diversity of the landscapes that shape this ecosystem. Indeed, the use of the concept of tropical savanna is often questioned and some experts considered it an extremely misused term ${ }^{5}$. One example that best characterizes the diverse possible range of its structural form is as follows:

forest (with closed tree canopy), arboreal woodland (with open tree canopy), tree and scrub woodland (trees more scattered and sharing prominence with scrub elements, all woody plants together forming an open layer), closed scrub, open scrub, grassland with scattered trees and shrubs equally prominent, grassland with scattered low shrubs only (the last three "savanna" in the strict structural sense), and grassland without any evidently visible woody plants ${ }^{6}$.

The complexity of the physiognomic types of the Cerrado's vegetation is expressed along with its landscape's diversity. The boundaries between these physiognomies are indeed arbitrary, "but researchers usually agree surprisingly well on the classification"7. The Cerrado is as well as the second largest Brazilian biome, and its location in the central plateau of South America puts it in contact with the most other Brazilian biomes such as the Amazon, the Caatinga, the Pantanal and the Atlantic Coastal Forest. The Cerrado is home to a rich biodiversity, in which includes almost 1,000 species of birds and nearly 300 mammals, most of them important to the perpetuation of this unique ecosystem ${ }^{8}$.

The human presence in this ecosystem has left records which archaeological research helps us to describe. The archaeological sources highlight the use of firewood which left records of a fire regime that reinforce the interference in the Cerrado's landscape. Importantly, archaeological studies point out that during the

\footnotetext{
${ }^{5}$ George Eiten, "The Cerrado Vegetation of Brazil," The Botanical Review 38, no. 2 (April 1972): 201-341, https://doi.org/10.1007/BF02859158.

6 lbid., p.202.

${ }^{7}$ Paulo S. Oliveira and Robert J. Marquis, "Introduction: Development of Research in the Cerrados," in The Cerrados of Brazil: Ecology and Natural History of a Neotropical Savanna, ed. Paulo Oliveira and Robert Marquis (New York Chichester, West Sussex: Columbia University Press, 2002), p.9, https://doi.org/10.7312/oliv12042.

${ }^{8}$ Oliveira and Marquis, "Introduction: Development of Research in the Cerrados."
} 
Holocene period the landscape and climate of the central plateau of Brazil were very similar to the current standards, presenting a typical physiognomy of what we currently consider to be the Cerrado biome, with the same seasonal tropical climate pattern $^{9}$.

The natural resources of the Cerrado began to be coveted and exploited with the first arrivals of Europeans, accelerated through processes of culturalenvironmental exchanges ${ }^{10}$ during five centuries of frontier expansion throughout the New World ${ }^{11}$. The introduction of exotic species such as African grasses and cultivars have drastically altered the Cerrado's landscapes ${ }^{12}$.

As Clarence Glacken noted, nature has always been a central category of human thought, especially in Western culture ${ }^{13}$. Starting from this premise, some issues are important for conducting an environmental history of the Cerrado: i) how have the natural characteristics of the Cerrado, influenced on the life of the societies that relate to it? ii) In which ways can environmental historians of the Cerrado accurately describe the anthropogenic transformations of its landscapes? ${ }^{14}$. More than establishing an argument capable of clarifying the socio-environmental complexities of the Cerrado, this article presents itself as an exploration of the doubts and challenges that reinforce these issues in historical terms.

\footnotetext{
9 Caroline Bachelet, "Pré-História No Cerrado: Análises Antracologicas Dos Abrigos de Santa Elina e Da Cidade de Pedra (Mato Grosso)," Fronteiras: Journal of Social, Technological and Environmental Science 3, no. 2 (December 28, 2014): 96, https://doi.org/10.21664/22388869.2014v3i2.p96-110; Altair Sales Barbosa, Sistema Biogeográfico Do Cerrado: Alguns Elementos Para Sua Caracterização (Goiânia: Editora UCG, 1996).

${ }_{10}$ Alfred W. Crosby, The Columbian Exchange: Biological and Cultural Consequences of 1492 (California: Greenwood Publishing Group, 1972); Alfred W. Crosby, Ecological Imperialism: The Biological Expansion of Europe, 900-1900 (New York: Cambridge University Press, 2009).

${ }^{11}$ Sergio Buarque de Holanda, Visão Do Paraíso: Os Motivos Edênicos No Descobrimento e Colonização Do Brasil (São Paulo: Companhia das Letras, 2010); Crosby, Ecological Imperialism: The Biological Expansion of Europe, 900-1900.

12 Sandro Dutra e Silva et al., "A Fronteira Do Gado e a Melinis Minutiflora P. Beauv. (POACEAE): A História Ambiental e as Paisagens Campestres Do Cerrado Goiano No Século XIX," Sustentabilidade Em Debate 6, no. 2 (August 31, 2015): 17-32, https://doi.org/10.18472/SustDeb.v6n2.2015.15469; Shawn Van Ausdal and Robert W. Wilcox, "Hoofprints: Ranching and Landscape Transformation," in New Environmental Histories of Latin America and the Caribbean, ed. Claudia Leal, José Augusto Pádua, and John Soluri (Munich: RCC Perspectives, 2013), 73-79, https://doi.org/doi.org/10.5282/rcc/6267; Robert W. Wilcox, Cattle in the Backlands: Mato Grosso and the Evolution of Ranching in the Brazilian Tropics (Austin: University of Texas Press, 2017); Sandro Dutra e Silva, No Oeste a Terra e o Céu: A Expansão Da Fronteira Agrícola No Brasil Central (Rio de Janeiro: Mauad X, 2017); Carlos Christian Della Giustina, "Degradação e Conservação Do Cerrado: Uma História Ambiental Do Estado de Goiás" (Universidade de Brasília, 2013); Carlos Christian Della Giustina, Sandro Dutra e Silva, and Eder de Souza Martins, "Geographic Reconstruction of a Central-West Brazilian Landscape Devastated during the First Half of the 20th Century: Mato Grosso de Goiás," Sustentabilidade Em Debate 9, no. 3 (December 28, 2018): 44-63, https://doi.org/10.18472/SustDeb.v9n3.2018.18588.

${ }^{13}$ Clarence J. Glacken, Traces on the Rhodian Shore: Nature and Culture in Western Thought from Ancient Times to the End of the Eighteenth Century (Berkeley: University of California Press, 1967).

14 Ibid.
} 
Since the late 1930s, the tropical forest areas of the Cerrado in Central Brazil have experienced the expansion of agricultural and demographic frontiers. The policy of frontier expansion was greatly supported and encouraged by Brazil's federal government in the form of land grants, technical support and farming equipment. In the 1940s and 1950s, the states of Goiás and Mato Grosso underwent projects of demographic occupation and agricultural colonization. The expansion of transportation networks through railway and roads connected the region with the country's main economic centers. In addition, the founding of the new federal capital, Brasília, in the late 1950s favored the integration of Central Brazil into the national economy ${ }^{15}$.

The environmental restrictions of the few remaining tropical forest areas in the Cerrado biome, with its favorable soils and climate for grain production, required the expansion and occupation of grasslands and shrublands of the Brazilian tropical savanna ${ }^{16}$. However, these botanical formations were the least fertile and least suitable regions for agricultural purposes.

Agronomic research conducted between the 1950s and 1970s favored the development of the Cerrado's agricultural potential. The creation of Embrapa (Brazilian Agricultural Research Corporation) in 1973 was a milestone in the expanding agricultural frontier along with the social-ecological transformation of this unique biome. Thus, starting in the 1970s, the Cerrado became a dynamic agricultural frontier, fueled by both public and private investment. These investments, spurred by an ideology of agricultural modernization, transformed the landscapes of Brazil's tropical savannas into one of the most important and powerful regions for food production within increasingly lucrative global markets ${ }^{17}$.

Meanwhile, recent studies of the expansion of the agricultural frontier in the Cerrado indicate that little remains of its original physiognomy. The remaining area of

\footnotetext{
${ }^{15}$ Dutra e Silva, No Oeste a Terra e o Céu: A Expansão Da Fronteira Agrícola No Brasil Central.

16 Preston E. James, "Trends in Brazilian Agricultural Development," Geographical Review 43, no. 3 (July 1953): 301-28, https://doi.org/10.2307/211750; Dutra e Silva, No Oeste a Terra e o Céu: A Expansão Da Fronteira Agrícola No Brasil Central; Leo Waibel, "Vegetation and Land Use in the Planalto Central of Brazil," Geographical Review 38, no. 4 (October 1948): 529-54, https://doi.org/10.2307/211442; Warren Dean, With Broadax and Firebrand: The Destruction of the Brazilian Atlantic Forest (Berkeley, Los Angeles, London: University of California Press, 1995).

${ }^{17}$ A historical analysis similar to William Cronon's discussion of the integration of the US Great Plains into global markets. See: William Cronon, Nature's Metropolis: Chicago and the Great West (New York/London: W. W. Norton \& Company, 1991).
} 
the Cerrado biome was estimated at $61.2 \%$, according to the Embrapa study of $2007^{18}$. In 2018, data from MapBiomas considered that only $57 \%$ of the Cerrado`s natural area remained, composed of forested and non-forested areas (Map 01). The most threatened area is Matopiba in the biome's northern region which, despite recent initiatives for its conservation and environmental protection, has become the latest Brazilian Frontier ${ }^{19}$. Another study carried out by the Institute for Environmental Research in the Amazon (IPAM) points out that between 2000 and 2015 the Cerrado's deforestation was more intense than in the Amazon. During that period, the Cerrado lost about 236,000 $\mathrm{km}^{2}$ of its native area, the size of the African country of Uganda. The loss in the Amazon, a biome twice as large, was about $208,000 \mathrm{~km}^{2}$, nonetheless represents a dramatic and costly loss ${ }^{20}$.

The unprecedented pace of deforestation in the Cerrado, as well as the manner in which environmental policies in Brazil have focused on biomes, present challenges for environmental historians. This paper therefore presents and discusses primary challenges for understanding the historical-environmental characteristics of the Cerrado and the processes that altered and continuously threaten the landscapes of this failing ecosystem.

\section{NATURAL Histories OF THE BRAZILIAN CERRADO}

The historical value of the Cerrado is largely due to the richness of its biodiversity ${ }^{21}$. The Cerrado is among the oldest biogeographical systems to evolve,

\footnotetext{
18 Edson Eyji Sano et al., "Mapeamento de Cobertura Vegetal Do Bioma Cerrado: Estatísticas e Resultados" (Planaltina (DF), 2007), https://www.infoteca.cnptia.embrapa.br/bitstream/doc/570887/1/doc190.pdf. 067ae94a2329; Bernardo B. N. Strassburg et al., "Moment of Truth for the Cerrado Hotspot," Nature Ecology \& Evolution 1, no. 4 (April 23, 2017): 1-3, https://doi.org/10.1038/s41559-017-0099.

21 James A. Ratter, Samuel Bridgewater, and J. Felipe Ribeiro, "Biodiversity Patterns of the Woody Vegetation of the Brazilian Cerrado," in Neotropical Savannas and Seasonally Dry Forests: Plant Diversity, Biogeography, and Conservation, ed. R. Toby Pennington and James A. Ratter (Boca Raton: CRC Press, 2006), 31-66, https://doi.org/10.1201/9781420004496-2; James A. Ratter et al., "Floristic Composition and Community Structure of a Southern Cerrado Area in Brazil," Notes from the Royal Botanic Garden, Edinburgh 45, no. 1 (1988): 137-51; James A. Ratter, J. Felipe Ribeiro, and Samuel Bridgewater, "The Brazilian Cerrado Vegetation and Threats to Its Biodiversity," Annals of Botany 80, no. 3 (1997): 223-30, https://doi.org/10.1006/anbo.1997.0469; Josana de Castro Peixoto et al., "Flavonoids from Brazilian Cerrado: Biosynthesis, Chemical and Biological Profile," Molecules 24, no. 16 (August 9, 2019): 2891, https://doi.org/10.3390/molecules24162891; Marcelo F. Simon and R. Toby Pennington, "Evidence for Adaptation to Fire Regimes in the Tropical Savannas of the Brazilian Cerrado," International Journal of Plant Sciences 173, no. 6 (July 2012): 711-23, https://doi.org/10.1086/665973.
} 
Map 01. Land Use and Land Cover of the Cerrado Biome in 2018.

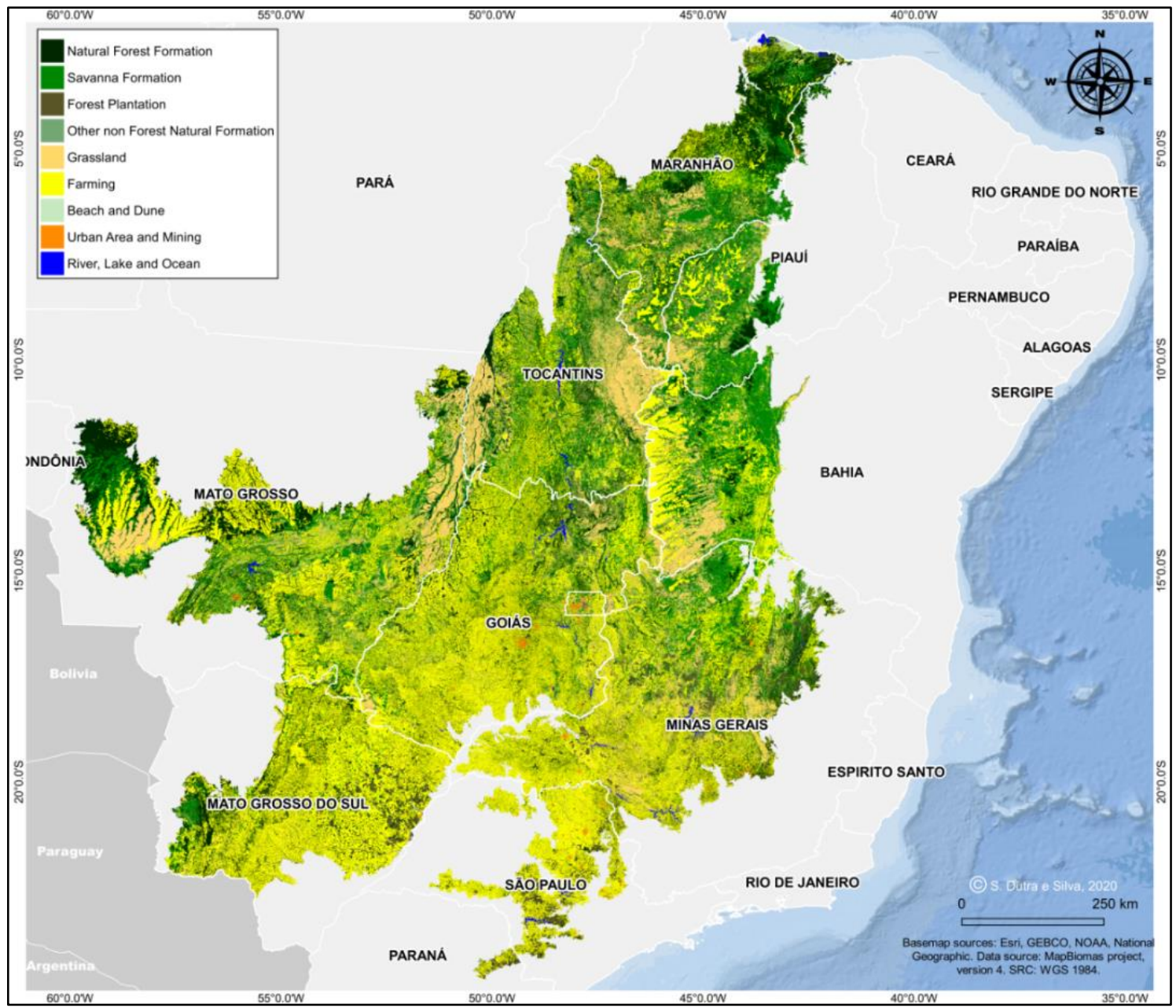

Source: MapBiomas.

emerging within the specific biophysical environment of the central plateaus of South America during the Cenozoic period around 30 to 40 million years ago ${ }^{22}$. Despite its ancient emergence, primary descriptions of the Cerrado's physiognomy remain quite accurate today. Early scientific records taken by European naturalists remain important sources for the natural and environmental history of this ecosystem. Guided by the scientific spirit of the $19^{\text {th }}$ century, widely disseminated in Europe by

\footnotetext{
22 Some studies work with the theory that Neotropical savannas occurred after the establishment of dry forests, in an estimated period of between 30 to 40 million years before the present. According to this theory, fire would have played a fundamental role in the emergence of the Neotropical savannas, inasmuch as it created the natural conditions for the establishment of resistant species. However, another theory considers the emergence of Neotropical savannas from grass registers and not from forest formations. In this sense, if the presence of a grassy stratum is a requirement for the definition of savannas, then this type of vegetation may have occurred from the beginning of the Eocene period (between 56 to 34 million years ago) when the first records of Poaceae appeared. For further additional information see: Marcelo F. Simon et al., "Recent Assembly of the Cerrado, a Neotropical Plant Diversity Hotspot, by in Situ Evolution of Adaptations to Fire," Proceedings of the National Academy of Sciences 106, no. 48 (2009): 20359-64, https://doi.org/10.1073/pnas.0903410106; Simon and Pennington, "Evidence for Adaptation to Fire Regimes in the Tropical Savannas of the Brazilian Cerrado"; Jorge Henrique Laux et al., "Two Neoproterozoic Crustal Accretion Events in the Brasilia Belt, Central Brazil," Journal of South American Earth Sciences 18, no. 2 (January 2005): 183-98, https://doi.org/10.1016/j.jsames.2004.09.003; Benjamin Bley de Brito Neves and Umberto G. Cordani, "Tectonic Evolution of South America during the Late Proterozoic," Precambrian Research 53, no. 1-2 (October 1991): 23-40, https://doi.org/10.1016/0301-9268(91)90004-T.
} 
Alexander von Humboldt's travels ${ }^{23}$, the scientific expeditions gathered collections and documented information that form a privileged record of the landscapes and frontiers of the Cerrado ecosystem ${ }^{24}$.

Many of these records occupy important collections in natural history museums around the world. These botanical descriptions, along with zoological, archaeological and geological collections, help us to understand the historical value of the Brazilian tropical savanna, as well as the real threats to biodiversity and the conservation of this important natural heritage. Descriptions of vegetation, for example, stem from the naturalist's attentive gaze. The concept of phytophysiognomy, which is a morphological characteristic of the plant community, was originally used by Humboldt to describe vegetation ${ }^{25}$.

The most important scientific expeditions of the landscapes responsible for the descriptions of the physiognomies of the Cerrado date from the beginning of the $19^{\text {th }}$ century, when the naturalists Johann Baptist Emanuel Pohl (1782-1834), Auguste de Saint-Hilaire (1779-1853), Carl F. von Martius (1794-1868), and Johann Baptist von Spix (1781-1826), explored the central plateaus of Brazil ${ }^{26}$.

The expedition coordinated by the physician and botanist Pohl was responsible for a rich collection of materials, which resulted in the seminal Plantarum Brasiliae Icones et Descriptiones hactenus ineditae, published in two volumes in 1826 and $1833^{27}$. Pohl's expedition to Central Brazil included the researchers Johann Mika, the taxidermist Johann Natterer and the landscape painter Thomas Ender. Part of the original material collected was deposited at the Natural History Museum in Vienna (Naturhistorisches Museum Wien). Along with material from the Atlantic Coast Forest, samples of fauna and flora from the Cerrado make up this fascinating scientific

\footnotetext{
${ }^{23}$ Andrea Wulf, The Invention of Nature: Alexander von Humboldt's New World (New York: Alfred A. Knoft, 2015); Pedro Sergio Urquijo Torres, Humboldt y El Jorullo: Historia de Una Exploración (México: Secretaria de Medio Ambiente y Recursos Naturales/Instituto Nacional de Ecologia (INE-SEMARNAT)/Universidade Nacional Autónoma de México, 2017).

${ }_{24}$ Carl Friedrich Philipp von Martius and H. Walter Lack, The Book of Palms (Köln: Taschen, 2015), https://doi.org/10.1093/aob/mcr211; Carl Friedrich Philipp von Martius and Johann Baptist von Spix, Viagens Pelo Brasil (Belo Horizonte/São Paulo: Ed. Itatiaia/Ed. Da Universidade de São Paulo, 1981); Auguste de Saint-Hilaire, Viagem à Província de Goiás (Belo Horizonte/São Paulo: Ed. Itatiaia/Editora da Universidade de São Paulo, 1975); George Gardner, Viagens No Interior Do Brasil: Principalmente Nas Províncias Do Norte e Nos Distritos Do Ouro e Do Diamante Durante Os Anos de 1836-1841 (São Paulo: Companhia Editora Nacional, 1975); Johann Emanuel Pohl, Viagem No Interior Do Brasil (Belo Horizonte/São Paulo: Ed. Itatiaia/Ed. da Universidade de São Paulo, 1976).

${ }^{25}$ G. Grabherr and S. Kojima, "Vegetation Diversity and Classification Systems," in Vegetation Dynamics \& Global Change, ed. A. M. Solomon and Herman H Shugart (Boston, MA: Springer US, 1993), 218-32, https://doi.org/10.1007/978-1-4615-2816-6_11.

26 Pohl, Viagem No Interior Do Brasil; Saint-Hilaire, Viagem à Província de Goiás; Martius and Spix, Viagens Pelo Brasil.

${ }^{27}$ Pohl, Viagem No Interior Do Brasil.
} 
collection, which became foundational in the formation European botanical knowledge ${ }^{28}$.

The German botanist, physician and anthropologist Carl F. von Martius (17941868) and the French artist Hercule Florence (1804-1879) were responsible for one of the most important visual records about the Cerrado. In 1823, Spix and Martius published the work Reise in Brasilien, and based on their collections in Brazil, they published Nova Genera et Species Plantarum and Historia Naturalis Palmarum ${ }^{29}$. In 1840, the work on Flora Brasiliensis began and was finally published in 1906. This work describes 22,767 sets of Brazilian flora species known in the $19^{\text {th }}$ century.

French botanist Saint-Hilaire presented materials, reports, and scientific notes from the Cerrado to the Natural History Museum of Paris, resulting in important publications. In 1824, he published Histoire des plantes les plus remarquables $d u$ Brésil and du Paraguay, and subsequently Plantes usuelles des Brasiliens (1824-1828) and Flora Brasilae Meridionalis (1825-1833). Alexander von Humboldt served as rapporteur for his work at the Paris Academy of Sciences in 1824 and 1825. According to the Annales des Sciences Naturelles, Humboldt praised the important research and botanical collection that Saint-Hilaire brought from Brazil to France. In 1830, after publishing an important set of works with very favorable reviews, Saint-Hilaire was admitted as a member to the Paris Academy of Sciences ${ }^{30}$.

However, the Cerrado's rich biodiversity has not always been associated with the aesthetic component of its landscapes, generating different perceptions and records of it. For instance, Saint-Hilaire's first impression of his trip to Goiás, described the landscape of Central Brazil as a scenario of monotony and boredom. In his words:

After ascending the mountains for a few moments, I found myself on a vast plateau, desert and quite regular. The terrain was sometimes covered with natural pastures and dotted with stunted trees. Sometimes it was exclusively grassing, and other times with herbs and sub-bushes as well. [...] There were

\footnotetext{
28 Thomas Adam, Germany and the Americas: Culture, Politics, and History : A Multidisciplinary Encyclopedia, vol. 1 (Santa Barbara (California): ABC Clio, 2005), https://doi.org/10.1108/09504120610709772; Christa Riedl-Dorn, Johann Natterer e a Missão Austriaca Para o Brasil (Petrópolis: Index, 1999).

${ }^{29}$ Martius and Spix, Viagens Pelo Brasil.

30 Lorelai Kury, "Auguste de Saint-Hilaire, Viajante Exemplar," Intellèctus 2, no. 1 (2003): 1-11.
} 
no more flowers and the landscape reminded me the region of Beauce, in France, shortly after the harvest ${ }^{31}$.

This record dated May 1819, when the French explorer had crossed the border into the Province of Minas Gerais from Goiás. Journeying through the backlands, Saint-Hilaire travelled through a great part of the Goiás territory. The reports of the naturalist describe the tough climate during his expedition with intense extremes of temperature. Chilly nights contrasted with intense heat and scorching sun in the afternoons. The explorer also described, with some disappointment, his impression of the landscapes of the Brazilian plateau. He saw the Cerrado as a region devoid of aesthetic beauty, especially compared with the exuberance of the Brazilian Atlantic Coast Forest. Of course, if the expedition had taken place during the rainy season his impressions and descriptions of the Cerrado's physiognomy would have been different due to seasonal changes in the landscapes.

A few decades after Saint-Hilaire's expedition, the Danish naturalist Eugenius Warming (1841-1924) offers yet another important description of the Brazilian Cerrado. Now considered a founding figure of the scientific discipline of ecology, Warming discussed his findings and impressions of the tropical savannas of Brazil in the monumental Symbolæ ad Floram Brasiliæ centralis cognoscendam, published in Copenhagen from 1867-1893 ${ }^{32}$. Dated from the beginning of May 1863, Warming's accounts changing landscape during a trip from Rio de Janeiro deep into the backlands. The trip included passages through the dramatic and verdant tropical forest. Crossing the ombrophilous forested region atop Mount Mantiqueira, he stepped into the vast Cerrado biome. Unlike Saint-Hilaire's apparent disappointment with Central Brazil, Warming was much more enthusiastic with the landscapes, flora, and fauna he encountered in the Cerrado. He described his fascination with this environment, which became fundamental in his academic trajectory in the field of natural history, especially in the botanical descriptions of Central Brazil's vegetation. In his words:

[...] Then the landscape opened up and the first flowered grasses appeared in front of us - we had arrived at the Cerrado. [...] The more we advanced, the

\footnotetext{
${ }^{31}$ Saint-Hilaire, Viagem à Província de Goiás.

32 Maria do Carmo Andrade Gomes, A Canção Das Palmeiras: Eugenius Warming, Um Jovem Botânico No Brasil (Belo Horizonte: Fundação João Pinheiro, 2006).
} 
clearer the landscape became apparent. The endless forests disappeared, and the terrain continued to ripple for another stretch until it flattened, forming the great plains... [...] In the Cerrado, we find ourselves in a flowery garden... $[\ldots]^{33}$.

The naturalist's descriptions reinforce the relationship between changes in the natural landscapes, and our perceptions of them. Based on the conflicting descriptions of the Cerrado by Saint-Hilaire and Warming, we can see how landscapes become both the outcome of natural evolution as well as of the sensory experience of humanity. They are altered by seasons that periodically intervene in natural landscapes, marking the passage of time within in physical and human environments. In the Cerrado this seasonality is marked by two great events: the wet season and the dry season.

Changes and transformations are ongoing: there is a time for rain, and a time for drought. A time for flowers, and a time when the foliage is dressed in a deep green. A time when the vegetation burns in the fire, leaving traces of ash and devastation. A time when waters and springs run slowly over pebbles in a calm that breaks the drama of the hostile scenery. A time when the swirling winds carry the dry leaves and dust of the earth in the dryness of August and September. Thus, the landscapes follow cyclical rhythms based on natural patterns of seasonality.

Culture and nature mingle in the evolutionary drama of landscape transformations, leading to profound environmental changes, at various rates of change. This is the greatest challenge in writing an environmental history of the Cerrado, because, like any ecosystem, the issues are not limited to its individual components, but are also expressed in their interactions. All environments are interactive environments. This complexity of seasonal and topographical change is even greater when we consider the historiographical exercise of accurately mapping the Cerrado within the discipline of environmental history.

Historians can take landscapes as a privileged document for environmental history. An environmental history of the Cerrado can be revealing in several ways, not only in the relationship between history and nature but in the history of nature

${ }^{33}$ Eugenius Warming, "Descrição Da Natureza Do Brasil Tropical, Especialmente Do Campo," in A Canção Das Palmeiras: Eugenius Warming, Um Jovem Botânico No Brasil, ed. Maria do Carmo Andrade Gomes (Belo Horizonte: Fundação João Pinheiro, 2006), p.56. 
itself $^{34}$. William Cronon warned us that geology, ecology and human history are all, somehow, history ${ }^{35}$. For him what makes these fields of knowledge historical are their relations to the evolutionary process of landscapes. In other words, they are all sciences that deal with the historical transformations of landscapes, which is indeed, an object and a historical document as well.

We can consider geology, for example, an important reference for an environmental history of the Cerrado. The Smithsonian archaeologist Altair Sales Barbosa advocates for the importance of understanding the Cerrado within the geological history of the planet ${ }^{36}$. The debate related to the origin of the Cerrado is an example to understand this ecosystem within the geological and archaeological frameworks of the planet. According to Ledru ${ }^{37}$ there are two great hypotheses related to the existence of the Brazilian tropical savanna: one anthropogenic and the other naturogenic. The former is based on human-induced origin of the Cerrado's vegetation, understood as resulting from the development of fire-adapted species from dry forests affected by wildfires. The latter hypothesis considers the natural origins of the Cerrado not as an achievement of human interaction with the landscape, but its emergence from the end of the Pleistocene period.

According to Barbosa ${ }^{38}$ the Cerrado was formed in this specific biophysical environment in the central plateaus of South America around 40 to 45 million years before the present. He based this claim on geological discoveries of fossilized seeds and foliage (figure 01) from that time period. This corresponds with the beginning of the Tertiary (Paleocene), when vast amounts of basalt created the geological formation known as Serra $\mathrm{Geral}^{39}$. The radioactive disintegration method was used to analyses the date of the fossilized seeds ${ }^{40}$, which is based on radiometric dating. The

\footnotetext{
${ }^{34}$ Donald Worster, Nature's Economy: A History of Ecological Ideas (New York: Cambridge University Press, 1994).

35 William Cronon, Changes in the Land: Indians, Colonists, and the Ecology of New England (New York: Hill and Wang, 2003).

${ }^{36}$ Barbosa, Sistema Biogeográfico Do Cerrado: Alguns Elementos Para Sua Caracterização.

${ }^{37}$ M. P. Ledru, "Late Quaternary History and Evolution of the Cerrados as Revealed by Palynological Records," in The Cerrados of Brazil - Ecology and Natural History of Neotropical Savanna, ed. Paulo S. Oliveira and Robert J. Marquis (New York: Columbia University Press, 2002), 33-50.

${ }^{38}$ Barbosa, Sistema Biogeográfico Do Cerrado: Alguns Elementos Para Sua Caracterização.

39 Horacio J. Harrington, "Paleogeographic Development of South America," AAPG Bulletin 46, no. 10 (1962): 1773-1814, https://doi.org/10.1306/BC7438F1-16BE-11D7-8645000102C1865D; Fernando Estevão Rodrigues Crincoli Pacheco et al., "Basaltic Ring Structures of the Serra Geral Formation at the Southern Triângulo Mineiro, Água Vermelha Region, Brazil," Journal of Volcanology and Geothermal Research 355 (April 2018): 136-48, https://doi.org/10.1016/j.jvolgeores.2017.06.019.

40 Celso Dal Ré Carneiro, Ana Maria Pimentel Mizusaki, and Fernando Flávio Marques de Almeida, "A Determinação Da Idade Das Rochas," Terrae Didatica 1, no. 1 (June 30, 2005): 6-35, https://doi.org/10.20396/td.v1i1.8637442.
} 
geochronology of mineral samples was developed at the Smithsonian Institute, with the collaboration of the distinguished archaeologist Betty Jane Meggers (1921 - 2012). After her passing in 2012 this important archaeological work ceased under budgetary constraints.

Figure 01. Fossilized Vegetation Seeds of the Cerrado.

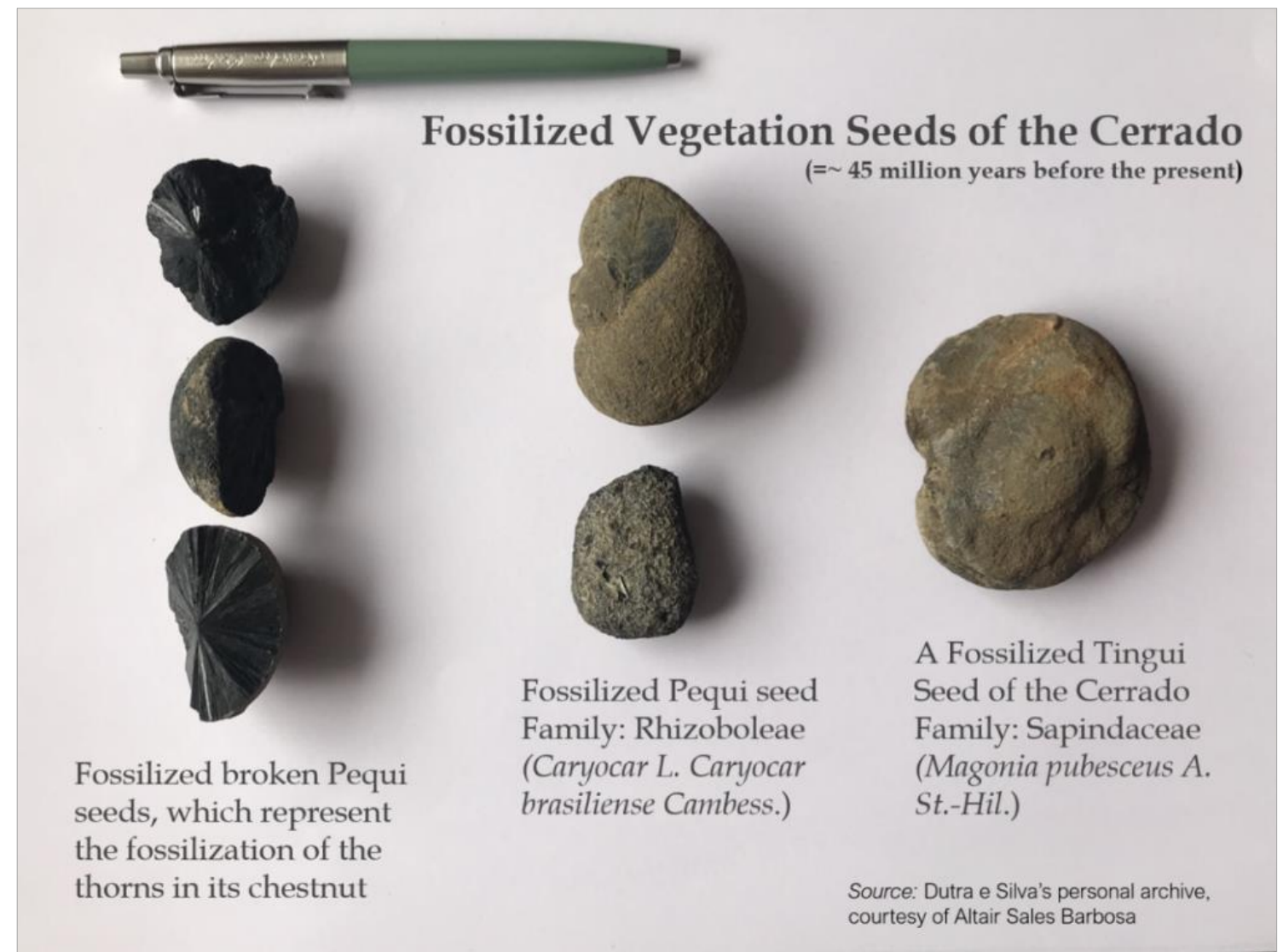

Source: S. Dutra e Silva's Personal Archive.

Barbosa criticized the limitations of the dominant and widespread biome concept. He advocates the concept of "biogeographic systems", considering that allnatural elements are closely intertwined ${ }^{41}$. The Cerrado as a biogeographic system cannot be considered only for its vegetative scope, characterized by a gradient that is expressed from grasslands and prairies to dense tropical forests. In terms of vegetation, the Cerrado is a mosaic of landscapes, whose modification in any of these ecosystem causes changes to other plant environments ${ }^{42}$. Considering the diversity of fauna and flora, the Cerrado can be classified as one of the largest assemblages of

\footnotetext{
${ }^{41}$ Barbosa, Sistema Biogeográfico Do Cerrado: Alguns Elementos Para Sua Caracterização.

42 Ratter, Bridgewater, and Ribeiro, "Biodiversity Patterns of the Woody Vegetation of the Brazilian Cerrado"; Ratter et al., "Floristic Composition and Community Structure of a Southern Cerrado Area in Brazil."
} 
biodiversity in the world ${ }^{43}$. This biogeographical system is characterized by the interaction between the different ecosystems, rather than their individual components.

The Cerrado's fauna exists in symbiosis with its flora. The extinction of some species of animals may affect the sprouting, and, in some cases, the extinction of plant species. An example of this symbiosis is the Araticum of the Cerrado (Anonacoriacea), a plant of the botanic family of Anonaceae. The sprouting of this plant occurs only after the fruit passes through the stomach of a wild native canine of the Brazilian tropical savanna. The extinction of these wild native canines, such as the maned wolf (Chrysocyon brachyurus), the wild dog (Cerdocyon thous) or the red cerrado fox (Lycalopex vetulus), directly affects the preservation of plant species, evidencing the biogeographic system of the Brazilian savanna ${ }^{44}$

This system also applies to groups of insect pollinators from the Cerrado, which evolved anatomically and appropriately for the pollination of respective plant species $^{45}$. The populations of these pollinators have been devastated by the indiscriminate use of agrochemicals and other pesticides, widely used in the cultivation of soybeans, as part of the broader expansion of the agricultural frontier ${ }^{46}$. This expansion has unfolded in an accelerated process of imbalance leading to the widespread elimination of native fauna, manifested perhaps most significantly with the loss of indigenous stingless bees ${ }^{47}$. This species of bees is responsible for the reproduction of approximately two-thirds of all plants that need cross-pollination in

\footnotetext{
43 J. C. Lenthall, S. Bridgewater, and P. A. Furley, "A Phytogeographic Analysis of the Woody Elements of New World Savannas," Edinburgh Journal of Botany 56, no. 2 (July 26, 1999): 293-305, https://doi.org/10.1017/S0960428600001153.

44 R. C. Paula and K. DeMatteo, "Maned Wolf: Chrysocyon Brachyurus," 2015, https://doi.org/https://dx.doi.org/10.2305/IUCN.UK.20154.RLTS.T4819A82316878.en; Barbosa, Sistema Biogeográfico Do Cerrado: Alguns Elementos Para Sua Caracterização; Beatriz de Mello Beisiegel et al., "Avaliação Do Risco de Extinção Do Cachorro-Do-Mato Cerdocyon Thous (Linnaeus, 1766) No Brasil," Biodiversidade Brasileira: Instituto Chico Mendes de Conservação Da Biodiversidade 3, no. 1 (2013): 138-45; Frederico Gemesio Lemos, Fernanda Cavalcanti de Azevedo, and Beatriz de Mello Beisiegel, "Avaliação Do Risco de Extinção Da Raposa-Do-Campo Lycalopex Vetulus (Lund, 1842) No Brasil," Biodiversidade Brasileira: Instituto Chico Mendes de Conservação Da Biodiversidade 3, no. 1 (2013): 160-71; Diego Queirolo et al., "Historical and Current Range of the Near Threatened Maned Wolf Chrysocyon Brachyurus in South America," Oryx 45, no. 2 (April 4, 2011): 296-303, https://doi.org/10.1017/S0030605310000372.

45 Gerhard Gottsberger, "Generalist and Specialist Pollination in Basal Angiosperms (ANITA Grade, Basal Monocots, Magnoliids, Chloranthaceae and Ceratophyllaceae): What We Know Now," Plant Diversity and Evolution 131, no. 4 (December 1, 2015): 263-362, https://doi.org/10.1127/pde/2015/0131-0085; Gerhard Gottsberger, "Beetle Pollination and Flowering Rhythm OfAnnona Spp. (Annonaceae) in Brazil," Plant Systematics and Evolution 167, no. 3-4 (1989): 165-87, https://doi.org/10.1007/BF00936404; Gerhard Gottsberger, Life in the Cerrado: A South American Tropical Seasonal Vegetation, vol. 2-Pollin (UIm: Reta Verlag, 2006).

${ }^{46}$ A. J. A. de Camargo et al., Mariposas Polinizadoras Do Cerrado: Identificação, Distribuição, Importância e Conservação (Planaltina (DF): Embrapa Cerrados, 2018).

47 David W. Roubik, Ecology and Natural History of Tropical Bees (Cambridge: Cambridge University Press, 1989), https://doi.org/10.1017/CBO9780511574641; Giorgio Cristino Venturieri, Criação de Abelhas Indígenas Sem Ferrão, 2nd ed. (Belém: Embrapa Amazônia Oriental, 2008).
} 
tropical forests. Stingless indigenous Jatahi bees (Tetragonisca angustula) have the greatest potential as pollinators, however the species has been endangered by the expansion of agricultural frontier (Figure 02) ${ }^{48}$.

Figure 02. The stingless Jatahi bees (Tetragonisca angustula).

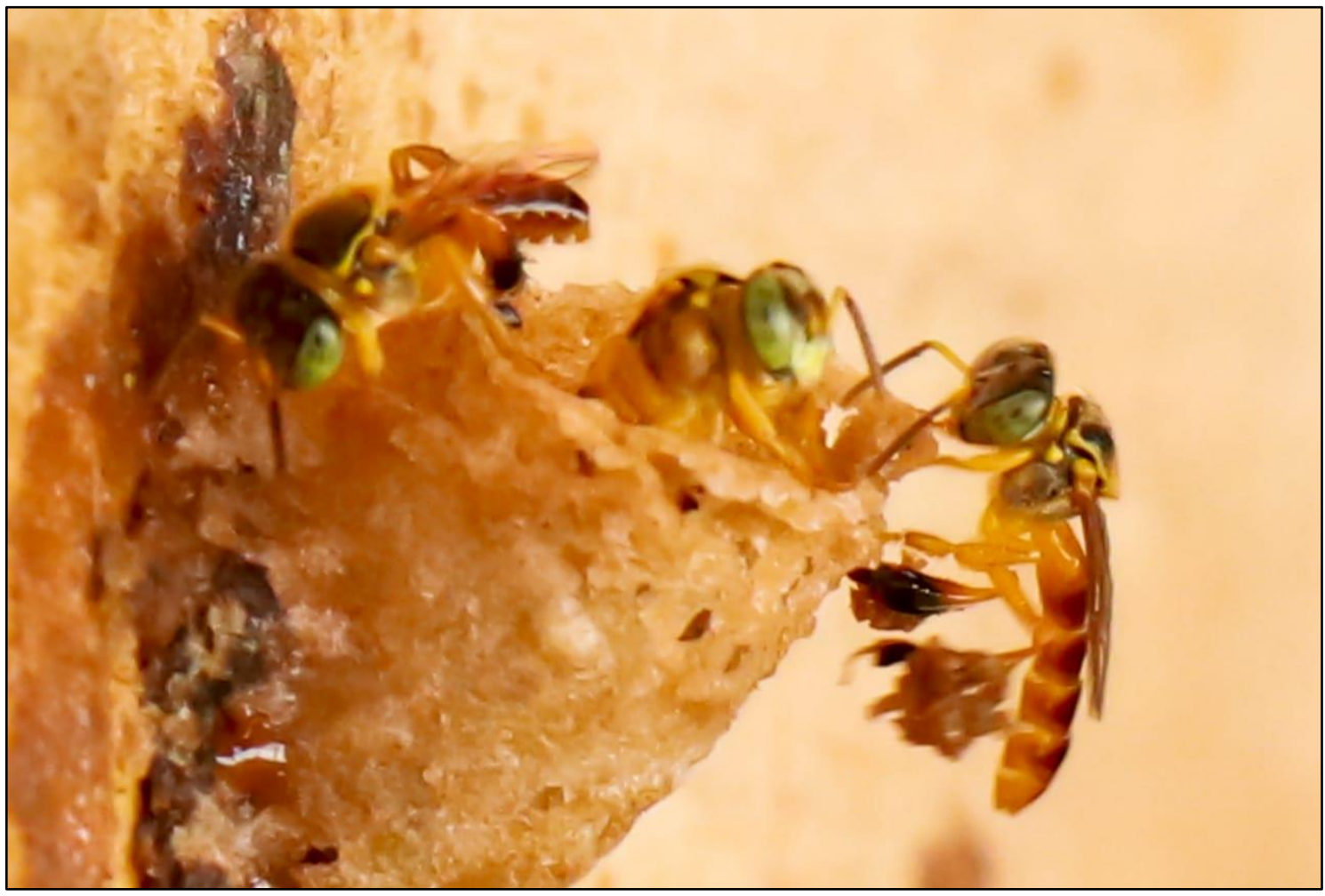

Photo: Teresa Fahey, Campo Limpo de Goiás, Brazil, 2019.

Another variable of this biophysical component is its weather patterns. The Cerrado environment has developed within a climatic pattern established millions of years ago, and which characterizes its seasonality. This weather patterns were densely sedimented from the beginning of the Pleistocene, when glaciation in the northern hemisphere affected climatic patterns in the Cerrado only minimally ${ }^{49}$. The average annual temperature in the Cerrado is $24^{\circ} \mathrm{C}$, which can vary between $40^{\circ} \mathrm{C}$ in the summer and down to $0^{\circ} \mathrm{C}$ in the winter. During those colder winter days, the presence of frosts can occur, especially in the southern Cerrado region ${ }^{50}$. The

\footnotetext{
48 W. E. Kerr et al., Abelha Uruçu - Biologia, Manejo e Conservação (Belo Horizonte: Fundação Acangau, 1996); Wainer Cesar Chiari et al., "Avaliação de Diferentes Modelos de Colméias Para Abelhas Jataí (Tetragonisca Angustula Latreille, 1811)," Acta Scientiarum. Animal Sciences 24 (2002): 881-87, https://doi.org/10.4025/actascianimsci.v24i0.2337; Gilton Mendes dos Santos and Yasmine Antonini, "The Traditional Knowledge on Stingless Bees (Apidae: Meliponina) Used by the Enawene-Nawe Tribe in Western Brazil," Journal of Ethnobiology and Ethnomedicine 4, no. 19 (December 15, 2008): 1-9, https://doi.org/10.1186/1746-4269-4-19.

49 V. M. Galvão, "Regiões Bioclimáticas," in Atlas Nacional Do Brasil (Rio de Janeiro: IBGE (Instituto Brasileiro de Geografia e Estatística), 1962); G. H. Hargreaves, Climate and Irrigation Requirements for Brazil (Logan: Utah State University, 1976); Aziz Nacib Ab'sáber, "The Natural Organization of Brazilian Inter-and Subtropical Landscapes," Revista Do Instituto Geológico 21, no. 1-2 (2000): 57-70, https://doi.org/10.5935/0100-929X.20000005.

${ }^{50}$ Fernando Antônio Macena da Silva et al., "Clima Do Bioma Cerrado," in Agricultura Tropical: Quatro Décadas de Inovações Tecnológicas,
} 
Pluviometric index presents an annual rainfall average of approximately $1,300 \mathrm{~mm}$ to $1,700 \mathrm{~mm}$ (51 to 67 inches). Much of the rainfall is concentrated in the months of October to April ${ }^{51}$. Between the months of July to August the humidity of the air drops significantly, between $15 \%$ and $30 \%$. This dry climate is a serious problem for the Cerrado vegetation, as it favors the appearance of wildfires ${ }^{52}$.

Wildfires are also another natural element associated with the biophysical history of the Cerrado. This is a complex and controversial subject, especially for historians ${ }^{53}$. However, natural fire is part of the ecological process responsible for the development of some ecosystems, such as the Cerrado, which is a fire-prone tropical savanna ${ }^{54}$. It can occur spontaneously, for example, between the months of August and September, when increased the incidences of wildfires. Ecologists have found that natural burning positively affects fauna and flora, which have adapted along with cycles of disruption and recovery induced by fires. Grasses and fire are, indeed, important subjects forgotten by environmental historians of the Cerrado ${ }^{55}$. Introduced in the $18^{\text {th }}$ century, exotic African grasses (e.g. Brachiaria decumbens) have come to dominate landscapes in Central Brazil, disrupting local fire regimes ${ }^{56}$.

Furthermore, the demographic expansion of the frontier and the forms of appropriation and exploitation of various natural resources constitute the greatest and most widely-discussed threats facing the ecosystem. The history of the uses of

Institucionais e Políticas, ed. Ana Christina Sagebin Albuquerque and Aliomar Gabriel da Silva, vol. 2 (Brasília: Embrapa Informação Tecnológica, 2008), 93-148.

51 Eduardo Delgado Assad, Chuva Nos Cerrados: Análise e Espacialização (Planaltina (DF)/Brasília: EMBRAPA-CPAC/EMBRAPA-SPI, 1994).

52 V. M. Galvão, "Clima," in Geografia Do Brasil. Grande Região Centro-Oeste (Rio de Janeiro: IBGE (Instituto Brasileiro de Geografia e Estatística), 1960), 71-118; Silva et al., "Clima Do Bioma Cerrado."

53 Stephen J. Pyne, Fire: A Brief History (Cycle of Fire) (Seattle/London: University of Washington Press, 2001); Stephen J. Pyne, America's Fires: A Historical Context for Policy and Practice (Durham, North Carolina: Forest History Society, 2010).

54 Letícia Gomes et al., "Post-Fire Recovery of Savanna Vegetation from Rocky Outcrops," Flora - Morphology, Distribution, Functional Ecology of Plants 209, no. 3-4 (March 2014): 201-8, https://doi.org/10.1016/j.flora.2014.02.006; Letícia Gomes, Heloisa Sinátora Miranda, and Mercedes Maria da Cunha Bustamante, "How Can We Advance the Knowledge on the Behavior and Effects of Fire in the Cerrado Biome?," Forest Ecology and Management 417 (May 2018): 281-90, https://doi.org/10.1016/j.foreco.2018.02.032; Leopoldo Magno Coutinho, "Aspectos Ecológicos Do Fogo No Cerrado. II - As Queimadas e a Dispersão de Sementes Em Algumas Espécies Anemocóricas Do Estrato Herbáceo-Subarbustivo," Boletim de Botânica 5 (June 25, 1977): 57-64, https://doi.org/10.11606/issn.2316-9052.v5i0p57-63; Raimundo P. B. Henriques, "Influência Da História, Solo e Fogo Na Distribuição e Dinâmica Das Fitofisionomias No Bioma Do Cerrado," in Cerrado: Ecologia, Biodiversidade e Conservação, ed. Aldicir Scariot, José Carlos Sousa-Silva, and Jeanine M. Felfili (Brasília: Ministério do Meio Ambiente, 2005), 73-92; Simon and Pennington, "Evidence for Adaptation to Fire Regimes in the Tropical Savannas of the Brazilian Cerrado."

55 Van Ausdal and Wilcox, "Hoofprints: Ranching and Landscape Transformation"; Matthew L. Brooks et al., "Effects of Invasive Alien Plants on Fire Regimes," BioScience 54, no. 7 (2004): 677-88; Heloisa S. Miranda, Mercedes M. C. Bustamante, and Antonio C. Miranda, "The Fire Factor," in The Cerrados of Brazil: Ecology and Natural History of a Neotropical Savanna, ed. Paulo S. Oliveira and Robert J. Marquis (New York: Columbia University Press, 2002), 51-68; Dutra e Silva et al., "A Fronteira Do Gado e a Melinis Minutiflora P. Beauv. (POACEAE): A História Ambiental e as Paisagens Campestres Do Cerrado Goiano No Século XIX."

${ }^{56}$ Coutinho, "Aspectos Ecológicos Do Fogo No Cerrado. II - As Queimadas e a Dispersão de Sementes Em Algumas Espécies Anemocóricas Do Estrato Herbáceo-Subarbustivo"; Henriques, "Influência Da História, Solo e Fogo Na Distribuição e Dinâmica Das Fitofisionomias No Bioma Do Cerrado"; Simon and Pennington, "Evidence for Adaptation to Fire Regimes in the Tropical Savannas of the Brazilian Cerrado." 
territorial concepts, delineating maps, paths and assimilation of physiognomies and landscapes, are examples of this intricate relationship. Dealing with concepts on a historical scale is a challenging exercise for environmental historians, particularly when we consider the designation of biomes as a recent historical phenomenon ${ }^{57}$.

Historians must deal not only with the concept of biomes but also with the concept's political use. The use of the concept of biome in Brazil has mistakenly acquired a floristic implication, when in fact its use is much broader and more complex than this. This is especially fraught for the Cerrado, which presents three distinct landscapes, such as the tropical grassland, the tropical savanna and the seasonal tropical forests ${ }^{58}$. Perhaps a more intriguing issue for environmental historians is to consider the political processes behind the delineation of territories and biomes. Brazil's Constitution of 1988 granted legal protection to the Amazon Rainforest, Atlantic Coast Forest (Mata Atlântica), Serra do Mar, Pantanal, and the Brazilian Coastline as environments of national heritage. ${ }^{59}$ The Cerrado and the Caatinga were not included on that list. The legislators privileged the Cerrado as an agricultural frontier, despite the inherent value of its biodiversity. Thus, due to the intersection of politics, ecology, and agricultural policy, the preservation of the Amazon has come at the cost of the Cerrado ${ }^{60}$. This article seeks not to detract from the Amazon, rather it calls for environmental histories of the Cerrado to highlight and promote critical socio-environmental issues and their wide-ranging ramifications.

\section{EXPANSION OF THE AGRICULTURAL FRONTIER}

Since the 1940s, federal policies and subsidies have encouraged the colonization of unsettled areas on the frontier regions in Central and Northern Brazil.

\footnotetext{
57 Leopoldo Magno Coutinho, "O Conceito de Bioma," Acta Botanica Brasilica 20, no. 1 (March 2006): 13-23, https://doi.org/10.1590/S010233062006000100002.

58 Ibid.; Marco Antônio Batalha, "O Cerrado Não é Um Bioma," Biota Neotropica 11, no. 1 (March 2011): 21-24, https://doi.org/10.1590/S167606032011000100001.

59 Brasil, "Constituição Da República Federativa Do Brasil de 1988" (1988), http://www.planalto.gov.br/ccivil_03/constituicao/constituicao.htm Título VIII, Da ordem Social, Capítulo VI, do Meio Ambiente, Artigo 225.

60 Spera, "Agricultural Intensification Can Preserve the Brazilian Cerrado: Applying Lessons From Mato Grosso and Goiás to Brazil's Last Agricultural Frontier"; H. K. Gibbs et al., "Brazil's Soy Moratorium," Science 347, no. 6220 (January 23, 2015): 377-78, https://doi.org/10.1126/science.aaa0181; D. C. Morton et al., "Cropland Expansion Changes Deforestation Dynamics in the Southern Brazilian Amazon," Proceedings of the National Academy of Sciences 103, no. 39 (September 26, 2006): 14637-41, https://doi.org/10.1073/pnas.0606377103; M. N. Macedo et al., "Decoupling of Deforestation and Soy Production in the Southern Amazon during the Late 2000s," Proceedings of the National Academy of Sciences 109, no. 4 (January 24, 2012): 1341-46, https://doi.org/10.1073/pnas.1111374109.
} 
Nevertheless, it was during the military era (1964-1985) that the Cerrado and the Amazon biomes were framed as strategic regions for the country's development. A series of National Development Policies (PNDs) guided the strategic processes of delineating the biomes, especially in their consideration as privileged areas for economic development. Since the 1940s, however, critical research of the Cerrado ecosystem was already underway in forward thinking universities and institutions in Brazil and beyond ${ }^{61}$. This research sought to realize the economic potential of this ecosystem, above all by detecting problems and finding solutions related to its nutrient-deficient soil characterized by elevated levels of aluminum, extremely hazardous to the production of commodities ${ }^{62}$. Pioneering research advanced the central strategies of an agricultural modernization campaign for the Cerrado - the management of soil acidity, soil drainage, fertilization and logistical infrastructures for grain storage.

The transformation of the Cerrado into an agricultural frontier for the production of commodities unfolded through complex processes ripe for historical inquiry. Early studies of the ecology and the geographical characteristics of the biome were associated with major government projects for agricultural modernization ${ }^{63}$. Embrapa created public research centers to study and enact regional agricultural development. These research units consisted of research centers for agricultural products, thematic research centers, and ecoregion research centers ${ }^{64}$. Created in 1974, the first centers specialized in the study of cattle, rubber trees, wheat, rice and

\footnotetext{
61 Robert Goodland, "Ecological Study of Cerrado Vegetation of South-Central Brazil" (McGill University, 1969); Mário Guimarães Ferri, "Observações Sobre Lagoa Santa," Ceres 4 (1943): 1-16; Mário Guimarães Ferri, "Transpiração de Plantas Permanentes Do 'Cerrado," Boletim Da Faculdade de Filosofia, Ciências e Letras, Universidade de São Paulo. Botânica 4 (1944): 159-224, https://doi.org/10.11606/issn.23185988.v4i0p155-224; Mário Guimarães Ferri, "Contribuição Ao Conhecimento Da Ecologia Do Cerrado e Da Caatinga. Estudo Comparativo Da Economia D'água de Sua Vegetação," Boletim Da Faculdade de Filosofia, Ciências e Letras, Universidade de São Paulo. Botânica 12 (1955): 7 170, https://doi.org/10.11606/issn.2318-5988.v12i0p7-170; Mário Guimarães Ferri and Leopoldo Magno Coutinho, "Contribuição Ao Conhecimento Da Ecologia Do Cerrado. Estudo Comparativo Da Economia D'água de Sua Vegetação, Em Emas (Est. de São Paulo), Campo Grande (Est. de Mato Grosso) e Goiânia (Est. de Goiás).," Boletim Da Faculdade de Filosofia, Ciências e Letras, Universidade de São Paulo. Botânica 15 (1958): 103-50, https://doi.org/10.11606/issn.2318-5988.v15i0p103-151; S. Faissol, Vegetação e Solos No Sudeste Do Planalto Central (Rio de Janeiro: Edição do Instituto Brasileiro de Geografia e Estatística, 1953); L. M. M. de Freitas, A. C. McClung, and W. L. Lott, Field Studies on Fertility Problems of Two Brazilian Campos Cerrados 1958-1959 (New York: IBEC Research Institute, 1960); K. Hueck, "Sobre a Origem Dos Campos Cerrados No Brasil e Algumas Novas Observações No Seu Limite Meridional," Revista Brasileira de Geografia 19, no. 1 (1957): 67-82; Leo Waibel, "A Vegetação e o Uso Da Terra No Planalto Central," Revista Brasileira de Geografia 10, no. 3 (1948): 335-80.

62 Goodland, "Ecological Study of Cerrado Vegetation of South-Central Brazil."

${ }^{63}$ Claiton Márcio da Silva, "A Face Infértil Do Brasil: Ciência, Recursos Hídricos e o Debate Sobre (in)Fertilidade Dos Solos Do Cerrado Brasileiro, 1892-1942," História, Ciências, Saúde-Manguinhos 26, no. 2 (April 2019): 483-500, https://doi.org/10.1590/s0104-59702019000200007; Embrapa. Centro de Pesquisa Abropecuária dos Cerrados, "Relatório Técnico Anual Do Centro de Pesquisa Agropecuária Dos Cerrados (1975-1977)" (Planaltina (DF), 1976); A. Dall'Agnol, A Embrapa Soja No Contexto Do Desenvolvimento Da Soja No Brasil: Histórico e Contribuições (Brasília: Embrapa Soja, 2016).

64 Dall'Agnol, A Embrapa Soja No Contexto Do Desenvolvimento Da Soja No Brasil: Histórico e Contribuições.
} 
beans $^{65}$. The Cerrado's Agricultural Research Center (CPAC) was established in 1975, publishing its first technical report in 1977. This document presented data and plans for the development of agriculture in the region, including a pioneering map of this ecosystem, delineating the "ecological transitional areas"66.

From the early 1980s and throughout the 1990s, the Cerrado became recognized as a thriving fertile frontier, producing commodities and cultivars central to foreign trade. Among the techniques used to transform the Cerrado into a thriving agricultural frontier, we highlight the advent of the use of lime to correct soil acidity, the use of synthetic fertilizers, pesticides, and mechanization. Another revolutionary technique, conducted mainly by Embrapa researchers, was the genetic improvement of agricultural cultivars, which in many cases resulted in the "tropicalization" of hybrid seeds such as soybeans, corn, rice and wheat. Other technological advances developed to inoculate bacteria in cultivars and to capture nitrogen in the soil, resulting in greater agricultural output with minimal fertilizer usage ${ }^{67}$.

Research on the Cerrado has increased significantly over the last two decades, and studies related to horticulture and livestock accounted for $24 \%$ of Brazil's international databased publications in the 1990s. The rapid transformation that took place through agricultural expansion required the establishment of georeferencing surveys, which resulted in the continuous monitoring of the biome ${ }^{68}$. During this period, spatial monitoring tools such as the Geographic Information System (GIS) began to quantify the effects of land use changes and water resources ${ }^{69}$.

In the 1990s, ecology, zoology, botany and mycology represented 54\% of all publications related to the studies of the Cerrado. From the 1970s, the creation of ecologically and agronomic oriented graduate programs in Brazil, was one of the main reasons for the significant increase in biological research of the Cerrado. The

\footnotetext{
65 lbid.

${ }^{66}$ Embrapa. Centro de Pesquisa Abropecuária dos Cerrados, "Relatório Técnico Anual Do Centro de Pesquisa Agropecuária Dos Cerrados (19751977)."

67 José Eustáquio Ribeiro Vieira Filho, Expansão Da Fronteira Agrícola No Brasil: Desafios e Perspectivas (Brasília/Rio de Janeiro: Ipea (Instituto de Pesquisa Econômica Aplicada), 2016).

68 Oliveira and Marquis, "Introduction: Development of Research in the Cerrados."

69 In 1994, the Image Processing and Geoprocessing Laboratory (LAPIG), linked to the Institute for Social Environmental Studies (IESA) of the Federal University of Goiás (UFG), started to operate. This laboratory has been responsible for numerous researches on edaphic interactions in land-use and land-coverage changeshttps://www.lapig.iesa.ufg.br/lapig/index.php
} 
remarkable development of natural and ecological research has increased the number of scientific papers on the Brazilian ecosystems, in particular, the Cerrado ${ }^{70}$.

The politicization of nature for scientific, agricultural and developmental purposes was part of Embrapa's institutional mandate, which started to perceive the Cerrado and the Amazon as strategic zones for frontier expansion. In recent decades the agricultural model of Embrapa has threatened a significant part of the natural, biotic and cultural heritage of the Cerrado. The whole agricultural sector celebrated the outstanding productivity rates achieved, particularly from the first decade of the $21^{\text {st }}$ century, when soybean production began to play an increasingly dominant role. According to data from the Brazilian Geographical Institute (IBGE) in the late 1990s, production of soybean in the Cerrado surpassed other biomes (chart 01). The agricultural production data monitored by the IBGE's Agricultural Atlas shows that in 2017 the Cerrado was responsible for $46.47 \%$ of all soybean production in Brazil ${ }^{71}$.

Chart 01. Historical Soybean Production by Brazilian Biomes (1990-2018).

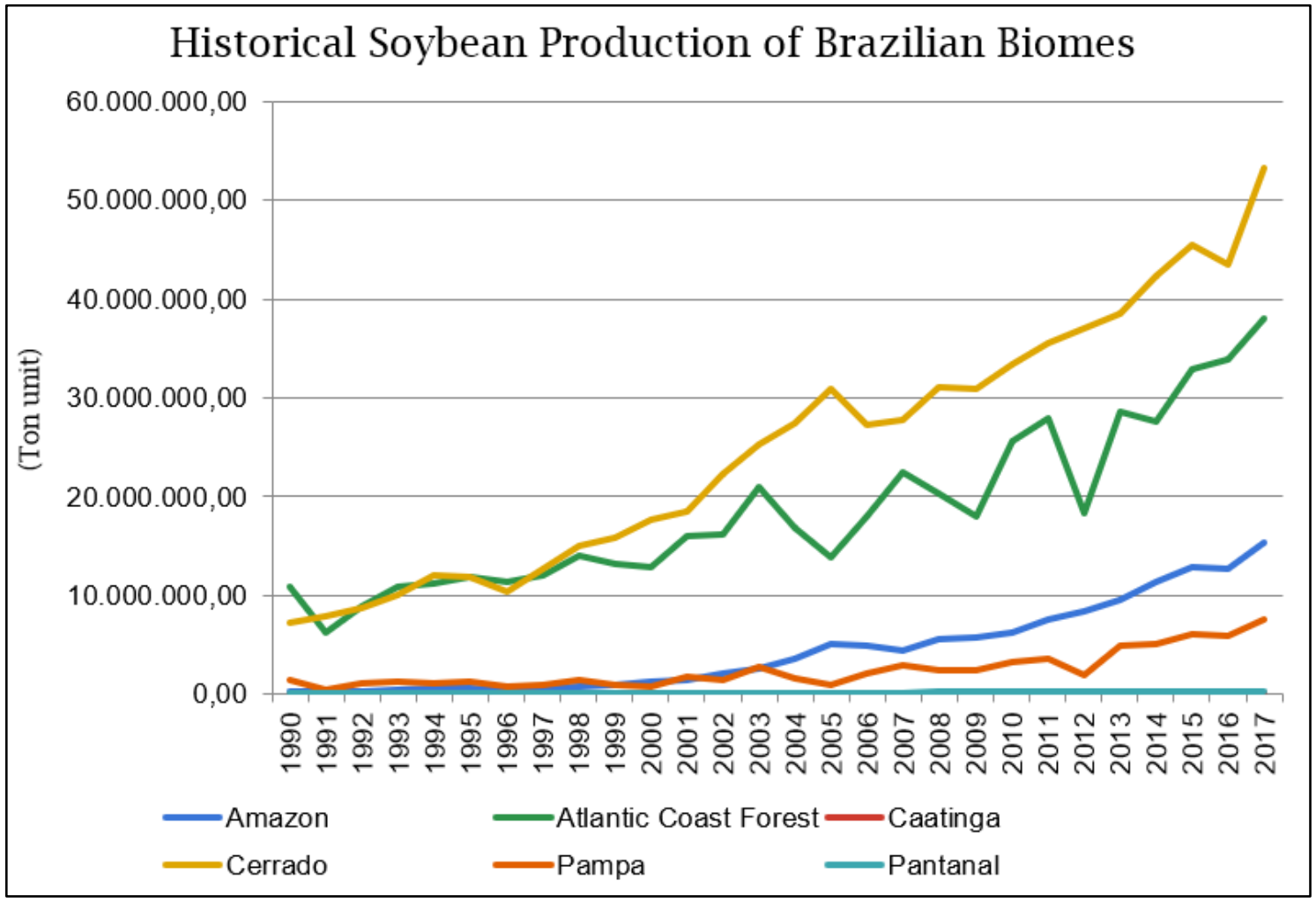

Source: Pesquisa Agrícola Municipal - PAM/IBGE, Atlas Agropecuário - IMAFLORA - 2019.

\footnotetext{
70 Oliveira and Marquis, "Introduction: Development of Research in the Cerrados."

71 Imaflora, "Atlas Da Agropecuária Brasileira," 2019, http://atlasagropecuario.imaflora.org/.
} 
The data on the advancement of soybean production in the Cerrado illustrate the success achieved by Embrapa's investments in scientific technology. This transformed a land once considered infertile into the most prominent area in terms of food Brazilian production. In addition to the amount of grain production, new forms of management and technological improvements in agronomical research have been applied to increase food productivity. According to Nehring, over "the last forty years, Embrapa carried out this vision to transform the Cerrado into one of the world's largest breadbaskets"72. Between 1970 and 2006, grain production in this region expanded from 8 million tons to over 48 million tons ${ }^{73}$.

The case of soybeans is a good example of this success as it highlights the impressive results of the economic development of agribusiness in Central Brazil. However, the agricultural expansion cycle has caused other effects, many of them negative, such as the massive rise in the value of arable land on the Cerrado. The consequences have been the geographical expansion of planted areas. In some cases, this expansion encroaches on territories with more restrictive environmental protection, such as the Amazon. Processes of agricultural expansion and development therefore represent a threat not only to the Cerrado but also to other ecosystems. According the data from the United States Department of Agriculture (USDA), projections for 2020 indicate that Brazil will become the world's largest soybean producer, surpassing the United States ${ }^{74}$ (chart 02). This projection, celebrated by Brazilian agribusiness, sounds a warning for environmentalists.

The Soy Moratorium, signed in 2006 in Brazil, was the first voluntary zero deforestation agreement implemented in the tropics. This agreement signed between the soy sectors and the government prohibited the commercialization of soy produced on deforested land in the Brazilian Amazon. Despite having established

\footnotetext{
72 Ryan Nehring, "Yield of Dreams: Marching West and the Politics of Scientific Knowledge in the Brazilian Agricultural Research Corporation (Embrapa)," Geoforum 77 (December 2016): 206-17, https://doi.org/10.1016/j.geoforum.2016.11.006.

${ }^{73}$ Carlos Augusto M. Santana and José Rente Nascimento, "Public Policies and Agricultural Investment in Brazil (Final Report)" (Brasília: Food and Agriculture Organization of the United Nations Policy Assistance Support Service (TCSP), 2012), http://www.fao.org/fileadmin/templates/tci/pdf/InvestmentPolicy/lnv_in_Br_agriculture_-_20_08_2012.pdf.

74 The United States Department of Agriculture, Foreign Agricultural Service DB USDA Soybean 1964-2019
} 
itself as an important mechanism for preventing the direct conversion of the Amazon into soybean cultivation, this has been to the detriment of the Cerrado ${ }^{75}$.

Chart 02. The historical series of soybean production of the six largest producing countries in the world.

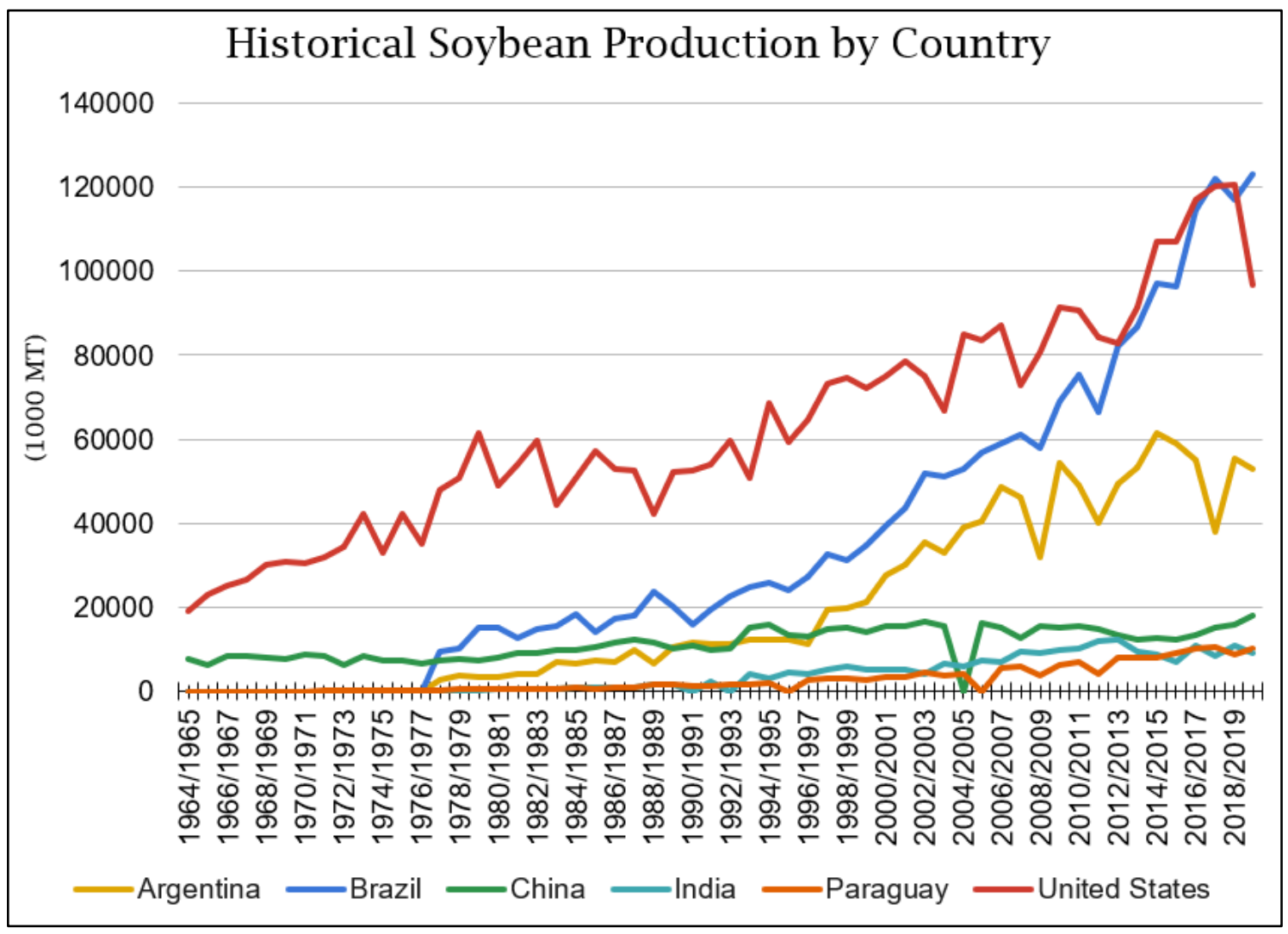

Source: PS\&D, Production, Supply and Distribution, USDA, 2020.

One of the most threatened areas in the Cerrado is the region known as the Matopiba, an acronym for the confluence of the states of Maranhão, Piauí, Tocantins, and Bahia. A report released by the USDA in July 2012 stated that the Matopiba was considered the latest emerging agricultural frontier in Brazil. Soy production there has increased rapidly over the previous 20 years, accounting for $10 \%$ of total Brazilian production.

The costs of agricultural growth on the Cerrado have come at a high price for this unique ecosystem, producing massive socio-environmental impacts including the destruction of the vegetative cover protecting the soil and subsoil; the extinction of species and erosion of biodiversity; the silting up and the reduction of the surface and underground drainage network; the destruction of centuries-old traditional cultures

75 Gibbs et al., "Brazil's Soy Moratorium." 
in rural communities; and the destruction of natural monuments and ancient archaeological sites.

\section{CONCLUSIONS}

An article published in Nature in 2017 drew attention to the apparent reduction of the Amazonian deforestation rates of about 70\%, between 2005 and 2013. The study stated, however, that this ephemeral celebration was overshadowed by the dramatic deforestation of the Cerrado. The researchers warned of an unprecedented global destruction of 200 million hectares of the great Brazilian tropical savanna. The main culprit behind this great ecological threat was overwhelming agribusiness $\operatorname{expansion}^{76}$.

Considering the historical process of development of the agricultural frontier, we can conclude that the research developed in the Cerrado was very successful based on its stated goals. Increasingly integrated into global markets, the Cerrado has become the leading producer of agricultural commodities among Brazilian biomes. Here I use the term "agricultural commodities," rather than "food production," as the transformation of the Cerrado has worked to deliver grains for agro-industrial supply chains (oils, animal feed, industrial products, etc.) more so than foods for hungry consumers. Most notably, the Cerrado is considered a "recession-proof region", because it is the region that best resisted Brazil's recent economic downturns.

In ecological terms, the Cerrado is a biophysical assemblage contoured by external challenges, just like any other ecosystem. Its complexity is related to the interactive outcomes of climatic, topographical, and edaphic factors. Furthermore, the environmental history of the Cerrado cannot disregard the effects of various interests related to the political processes guiding agricultural modernization and the territorial delimitations of Brazilian biomes. This is because the concept of "agricultural frontier" is associated with a particular type of land use, intensified by the technological advances in food production. Agricultural expansion is therefore moving towards the rapid transformation of natural landscapes and the extinction of

\footnotetext{
${ }^{76}$ Strassburg et al., "Moment of Truth for the Cerrado Hotspot."
} 
species of this essential biogeographical system. Moreover, the study of biomes must be widened to include long-term political consequences to the environment, both within and well beyond any ecological transformations.

Donald Worster has warned us that the wealth of nature, once appropriated, perceived and used, is able to stimulate people's material conditions, but also transforms the ways they come to understand nature itself ${ }^{77}$. This dominant, Western ethos is based on the idea that nature should be conceived as a form of capital. This ethos has therefore helped to institutionalize myths of control over nature, cultivating an optimistic belief in human abilities. At the same time, this ethos has fostered an insatiable hunger for natural resources, based on an enthusiastic belief in technological improvements. While scientific development allows making better use of natural resources, it expands the domain over these same resources, limited and reduced ever so. Understanding, debating and historicizing these processes represent, indeed, profound challenges for environmental historians, regardless of the ecosystems they study, as we speak of a world without borders ${ }^{78}$. All of this is true, but at the same time it highlights the necessity of a counter-narrative, which includes ecologists, conservation biologists, and other scientists, as well as political activists and even environmental historians. In other words, the many critics of the dominant Western ethos have enjoyed much more success influencing the trajectories of other Brazilian biomes, such as the Amazon and the Atlantic Coast Forest. A key challenge for environmental historians lies in constructing this counter-narrative of the Cerrado, an analytical but also political project, which emphasizes its singular ecological heritage as much as its economic value.

\section{ACKNOLEDGMENTS}

Sandro Dutra e Silva would like to thank the National Council for Scientific and Technological Development (CNPq) for his research grant. The author thanks the

\footnotetext{
77 Donald Worster, Dust Bowl: The Southern Plains in the 1930s (New York: Oxford University Press, 1979); Donald Worster, Shrinking the Earth: The Rise and Decline of American Abundance (New York: OUP (USA), 2016); Worster, "World without Borders: The Internationalizing of Environmental History."

78 Worster, "World without Borders: The Internationalizing of Environmental History"; Mark D. Hersey and Ted Steinberg, A Field on Fire: The Future of Environmental History (Tuscaloosa: The University of Alabama Press, 2019).
} 
blinded peer reviewers for their important suggestions. He also thanks the accurate reading and suggestions given by Tyrone Fahey, Stuart McCook, Benjamim Evans, Matthew Johnson, and Case Watkins.

\section{REFERENCIAS}

Ab'sáber, Aziz Nacib. "The Natural Organization of Brazilian Inter-and Subtropical Landscapes." Revista Do Instituto Geológico 21, no. 1-2 (2000): 57-70. https://doi.org/10.5935/0100-929X.20000005.

Adam, Thomas. Germany and the Americas: Culture, Politics, and History : A Multidisciplinary Encyclopedia. Vol. 1. Santa Barbara (California): ABC Clio, 2005. https://doi.org/10.1108/09504120610709772.

Assad, Eduardo Delgado. Chuva Nos Cerrados: Análise e Espacialização. Planaltina (DF)/Brasília: EMBRAPA-CPAC/EMBRAPA-SPI, 1994.

Ausdal, Shawn Van, and Robert W. Wilcox. "Hoofprints: Ranching and Landscape Transformation." In New Environmental Histories of Latin America and the Caribbean, edited by Claudia Leal, José Augusto Pádua, and John Soluri, 73-79. Munich: RCC Perspectives, 2013. https://doi.org/doi.org/10.5282/rcc/6267.

Bachelet, Caroline. "Pré-História No Cerrado: Análises Antracologicas Dos Abrigos de Santa Elina e Da Cidade de Pedra (Mato Grosso)." Fronteiras: Journal of Social, Technological and Environmental Science 3, no. 2 (December 28, 2014): 96. https://doi.org/10.21664/2238-8869.2014v3i2.p96-110.

Barbosa, Altair Sales. Sistema Biogeográfico Do Cerrado: Alguns Elementos Para Sua Caracterização. Goiânia: Editora UCG, 1996.

Batalha, Marco Antônio. "O Cerrado Não é Um Bioma." Biota Neotropica 11, no. 1 (March 2011): 21-24. https://doi.org/10.1590/S1676-06032011000100001.

Beisiegel, Beatriz de Mello, Frederico Gemesio Lemos, Fernanda Cavalcanti de Azevedo, Diego Queirolo, and Rodrigo Silva Pinto Jorge. "Avaliação Do Risco de Extinção Do Cachorro-Do-Mato Cerdocyon Thous (Linnaeus, 1766) No Brasil." Biodiversidade Brasileira: Instituto Chico Mendes de Conservação Da Biodiversidade 3, no. 1 (2013): 138-45.

Brasil. Constituição da República Federativa do Brasil de 1988 (1988). http://www.planalto.gov.br/ccivil_03/constituicao/constituicao.htm.

Brito Neves, Benjamin Bley de, and Umberto G. Cordani. "Tectonic Evolution of South America during the Late Proterozoic." Precambrian Research 53, no. 1-2 (October 1991): 23-40. https://doi.org/10.1016/0301-9268(91)90004-T.

Brooks, Matthew L., Carla M. D’Antonio, David M. Richardson, James B. Grace, Jon E. 
Keeley, Joseph M. DiTomaso, Richard J. Hobbs, Mike Pellant, and David Pyke. "Effects of Invasive Alien Plants on Fire Regimes." BioScience 54, no. 7 (2004): 67788.

Camargo, A. J. A. de, W. R. F. de Camargo, D. do C. V. Corrêa, M. de F. Vilela, and F. W. Amorim. Mariposas Polinizadoras Do Cerrado: Identificação, Distribuiçãa, Importância e Conservação. Planaltina (DF): Embrapa Cerrados, 2018.

Carneiro, Celso Dal Ré, Ana Maria Pimentel Mizusaki, and Fernando Flávio Marques de Almeida. "A Determinação Da Idade Das Rochas." Terrae Didatica 1, no. 1 (June 30, 2005): 6-35. https://doi.org/10.20396/td.v1i1.8637442.

Carvalho, André Fernando Araújo de. "Supressão Da Vegetação Nativa Para o Bioma Cerrado à Partir de 2000 (Raster)." Divisão de Processamento de Imagens DPI/OBT/INPE, 2019.

http://terrabrasilis.dpi.inpe.br/geonetwork/srv/api/records/333db098-86ec4447-a8b8-067ae94a2329.

Chiari, Wainer Cesar, Valéria Maria Attencia, Adriano Ernesto de Toledo Fritzen, Vagner De Alencar Arnaut de Toledo, Yoko Terada (in memorian), Maria Claudia Colla Ruvolo-Takasusuki, Fábio Luiz Buranelo Toral, and Guilherme José de Paiva. "Avaliação de Diferentes Modelos de Colméias Para Abelhas Jataí (Tetragonisca Angustula Latreille, 1811)." Acta Scientiarum. Animal Sciences 24 (2002): 881-87. https://doi.org/10.4025/actascianimsci.v24i0.2337.

Coutinho, Leopoldo Magno. "Aspectos Ecológicos Do Fogo No Cerrado. II - As Queimadas e a Dispersão de Sementes Em Algumas Espécies Anemocóricas Do Estrato Herbáceo-Subarbustivo." Boletim de Botânica 5 (June 25, 1977): 57-64. https://doi.org/10.11606/issn.2316-9052.v5i0p57-63.

---. "O Conceito de Bioma." Acta Botanica Brasilica 20, no. 1 (March 2006): 13-23. https://doi.org/10.1590/S0102-33062006000100002.

Cronon, William. Changes in the Land: Indians, Colonists, and the Ecology of New England. New York: Hill and Wang, 2003.

---. Nature's Metropolis: Chicago and the Great West. New York/London: W. W. Norton \& Company, 1991.

Crosby, Alfred W. Ecological Imperialism: The Biological Expansion of Europe, 9001900. New York: Cambridge University Press, 2009.

---. The Columbian Exchange: Biological and Cultural Consequences of 1492. California: Greenwood Publishing Group, 1972.

Dall'Agnol, A. A Embrapa Soja No Contexto Do Desenvolvimento Da Soja No Brasil: Histórico e Contribuições. Brasília: Embrapa Soja, 2016.

Dean, Warren. With Broadax and Firebrand: The Destruction of the Brazilian Atlantic Forest. Berkeley, Los Angeles, London: University of California Press, 1995. 
Dutra e Silva, Sandro. No Oeste a Terra e o Céu: A Expansão Da Fronteira Agrícola No Brasil Central. Rio de Janeiro: Mauad X, 2017.

Dutra e Silva, Sandro, Kárita de Jesus Boaventura, Eder Dasdoriano Porfírio Júnior, and Carlos de Melo e Silva Neto. "A Última Fronteira Agrícola Do Brasil: O Matopiba e Os Desafios de Proteção Ambiental No Cerrado." Estudios Rurales 8, no. Especial (2018): 145-78.

Dutra e Silva, Sandro, Rosimeire Mateus, Vivian Braz, and Josana Peixoto. "A Fronteira Do Gado e a Melinis Minutiflora P. Beauv. (POACEAE): A História Ambiental e as Paisagens Campestres Do Cerrado Goiano No Século XIX." Sustentabilidade Em Debate 6, no. 2 (August 31, 2015): 17-32. https://doi.org/10.18472/SustDeb.v6n2.2015.15469.

Eiten, George. "The Cerrado Vegetation of Brazil." The Botanical Review 38, no. 2 (April 1972): 201-341. https://doi.org/10.1007/BF02859158.

Embrapa. Centro de Pesquisa Abropecuária dos Cerrados. "Relatório Técnico Anual Do Centro de Pesquisa Agropecuária Dos Cerrados (1975-1977)." Planaltina (DF), 1976.

Faissol, S. Vegetação e Solos No Sudeste Do Planalto Central. Rio de Janeiro: Edição do Instituto Brasileiro de Geografia e Estatística, 1953.

Ferri, Mário Guimarães. "Contribuição Ao Conhecimento Da Ecologia Do Cerrado e Da Caatinga. Estudo Comparativo Da Economia D’água de Sua Vegetação." Boletim Da Faculdade de Filosofia, Ciências e Letras, Universidade de São Paulo. Botânica 12 (1955): 7-170. https://doi.org/10.11606/issn.2318-5988.v12i0p7-170.

---. "Observações Sobre Lagoa Santa." Ceres 4 (1943): 1-16.

---. "Transpiração de Plantas Permanentes Do 'Cerrado." Boletim Da Faculdade de Filosofia, Ciências e Letras, Universidade de São Paulo. Botânica 4 (1944): 159-224. https://doi.org/10.11606/issn.2318-5988.v4i0p155-224.

Ferri, Mário Guimarães, and Leopoldo Magno Coutinho. "Contribuição Ao Conhecimento Da Ecologia Do Cerrado. Estudo Comparativo Da Economia D’água de Sua Vegetação, Em Emas (Est. de São Paulo), Campo Grande (Est. de Mato Grosso) e Goiânia (Est. de Goiás)." Boletim Da Faculdade de Filosofia, Ciências e Letras, Universidade de São Paulo. Botânica 15 (1958): 103-50. https://doi.org/10.11606/issn.2318-5988.v15i0p103-151.

Freitas, L. M. M. de, A. C. McClung, and W. L. Lott. Field Studies on Fertility Problems of Two Brazilian Campos Cerrados 1958-1959. New York: IBEC Research Institute, 1960.

Galvão, V. M. "Clima." In Geografia Do Brasil. Grande Região Centro-Oeste, 71-118. Rio de Janeiro: IBGE (Instituto Brasileiro de Geografia e Estatística), 1960.

---. "Regiões Bioclimáticas." In Atlas Nacional Do Brasil. Rio de Janeiro: IBGE 
(Instituto Brasileiro de Geografia e Estatística), 1962.

Gardner, George. Viagens No Interior Do Brasil: Principalmente Nas Províncias Do Norte e Nos Distritos Do Ouro e Do Diamante Durante Os Anos de 1836-1841. São Paulo: Companhia Editora Nacional, 1975.

Gibbs, H. K., L. Rausch, J. Munger, I. Schelly, D. C. Morton, P. Noojipady, B. SoaresFilho, P. Barreto, L. Micol, and N. F. Walker. "Brazil's Soy Moratorium." Science 347, no. 6220 (January 23, 2015): 377-78. https://doi.org/10.1126/science.aaa0181.

Giustina, Carlos Christian Della. "Degradação e Conservação Do Cerrado: Uma História Ambiental Do Estado de Goiás." Universidade de Brasília, 2013.

Giustina, Carlos Christian Della, Sandro Dutra e Silva, and Eder de Souza Martins. "Geographic Reconstruction of a Central-West Brazilian Landscape Devastated during the First Half of the 20th Century: Mato Grosso de Goiás." Sustentabilidade Em Debate 9, no. 3 (December 28, 2018): 44-63. https://doi.org/10.18472/SustDeb.v9n3.2018.18588.

Glacken, Clarence J. Traces on the Rhodian Shore: Nature and Culture in Western Thought from Ancient Times to the End of the Eighteenth Century. Berkeley: University of California Press, 1967.

Gomes, Letícia, Leandro Maracahipes, Beatriz Schwantes Marimon, Simone Matias Reis, Fernando Elias, Leonardo Maracahipes-Santos, Ben Hur Marimon-Junior, and Eddie Lenza. "Post-Fire Recovery of Savanna Vegetation from Rocky Outcrops." Flora - Morphology, Distribution, Functional Ecology of Plants 209, no. 3-4 (March 2014): 201-8. https://doi.org/10.1016/j.flora.2014.02.006.

Gomes, Letícia, Heloisa Sinátora Miranda, and Mercedes Maria da Cunha Bustamante. "How Can We Advance the Knowledge on the Behavior and Effects of Fire in the Cerrado Biome?" Forest Ecology and Management 417 (May 2018): 281-90. https://doi.org/10.1016/j.foreco.2018.02.032.

Gomes, Maria do Carmo Andrade. A Canção Das Palmeiras: Eugenius Warming, Um Jovem Botânico No Brasil. Belo Horizonte: Fundação João Pinheiro, 2006.

Goodland, Robert. "Ecological Study of Cerrado Vegetation of South-Central Brazil." McGill University, 1969.

Gottsberger, Gerhard. "Beetle Pollination and Flowering Rhythm OfAnnona Spp. (Annonaceae) in Brazil." Plant Systematics and Evolution 167, no. 3-4 (1989): 16587. https://doi.org/10.1007/BF00936404.

---. "Generalist and Specialist Pollination in Basal Angiosperms (ANITA Grade, Basal Monocots, Magnoliids, Chloranthaceae and Ceratophyllaceae): What We Know Now." Plant Diversity and Evolution 131, no. 4 (December 1, 2015): 263-362. https://doi.org/10.1127/pde/2015/0131-0085.

---. Life in the Cerrado: A South American Tropical Seasonal Vegetation. Vol. 2-Pollin. 
Ulm: Reta Verlag, 2006.

Grabherr, G., and S. Kojima. "Vegetation Diversity and Classification Systems." In Vegetation Dynamics \& Global Change, edited by A. M. Solomon and Herman H Shugart, 218-32. Boston, MA: Springer US, 1993. https://doi.org/10.1007/978-14615-2816-6_11.

Hargreaves, G. H. Climate and Irrigation Requirements for Brazil. Logan: Utah State University, 1976.

Harrington, Horacio J. "Paleogeographic Development of South America." AAPG Bulletin 46, no. 10 (1962): 1773-1814. https://doi.org/10.1306/BC7438F1-16BE11D7-8645000102C1865D.

Henriques, Raimundo P. B. "Influência Da História, Solo e Fogo Na Distribuição e Dinâmica Das Fitofisionomias No Bioma Do Cerrado." In Cerrado: Ecologia, Biodiversidade e Conservação, edited by Aldicir Scariot, José Carlos Sousa-Silva, and Jeanine M. Felfili, 73-92. Brasília: Ministério do Meio Ambiente, 2005.

Hersey, Mark D., and Ted Steinberg. A Field on Fire: The Future of Environmental History. Tuscaloosa: The University of Alabama Press, 2019.

Holanda, Sergio Buarque de. Visão Do Paraíso: Os Motivos Edênicos No Descobrimento e Colonização Do Brasil. São Paulo: Companhia das Letras, 2010.

Hueck, K. "Sobre a Origem Dos Campos Cerrados No Brasil e Algumas Novas Observações No Seu Limite Meridional." Revista Brasileira de Geografia 19, no. 1 (1957): 67-82.

Imaflora. "Atlas Da Agropecuária Brasileira," 2019. http://atlasagropecuario.imaflora.org/.

James, Preston E. "Trends in Brazilian Agricultural Development." Geographical Review 43, no. 3 (July 1953): 301-28. https://doi.org/10.2307/211750.

Kerr, W. E., G. A. Carvalho, V. A. Nascimento, L. R. Bego, R. M. de O. Alves, M. A. S. Martins, and I. C. e Souza. Abelha Uruçu - Biologia, Manejo e Conservação. Belo Horizonte: Fundação Acangau, 1996.

Kury, Lorelai. "Auguste de Saint-Hilaire, Viajante Exemplar." Intellèctus 2, no. 1 (2003): $1-11$.

Laux, Jorge Henrique, Márcio Martins Pimentel, Elton Luiz Dantas, Richard Armstrong, and Sergio Luiz Junges. "Two Neoproterozoic Crustal Accretion Events in the Brasília Belt, Central Brazil." Journal of South American Earth Sciences 18, no. 2 (January 2005): 183-98. https://doi.org/10.1016/j.jsames.2004.09.003.

Ledru, M. P. "Late Quaternary History and Evolution of the Cerrados as Revealed by Palynological Records." In The Cerrados of Brazil - Ecology and Natural History of 
Neotropical Savanna, edited by Paulo S. Oliveira and Robert J. Marquis, 33-50. New York: Columbia University Press, 2002.

Lemos, Frederico Gemesio, Fernanda Cavalcanti de Azevedo, and Beatriz de Mello Beisiegel. "Avaliação Do Risco de Extinção Da Raposa-Do-Campo Lycalopex Vetulus (Lund, 1842) No Brasil." Biodiversidade Brasileira: Instituto Chico Mendes de Conservação Da Biodiversidade 3, no. 1 (2013): 160-71.

Lenthall, J. C., S. Bridgewater, and P. A. Furley. "A Phytogeographic Analysis of the Woody Elements of New World Savannas." Edinburgh Journal of Botany 56, no. 2 (July 26, 1999): 293-305. https://doi.org/10.1017/S0960428600001153.

Macedo, M. N., R. S. DeFries, D. C. Morton, C. M. Stickler, G. L. Galford, and Y. E. Shimabukuro. "Decoupling of Deforestation and Soy Production in the Southern Amazon during the Late 2000s." Proceedings of the National Academy of Sciences 109, no. 4 (January 24, 2012): 1341-46. https://doi.org/10.1073/pnas.1111374109.

Martius, Carl Friedrich Philipp von, and H. Walter Lack. The Book of Palms. Köln: Taschen, 2015. https://doi.org/10.1093/aob/mcr211.

Martius, Carl Friedrich Philipp von, and Johann Baptist von Spix. Viagens Pelo Brasil. Belo Horizonte/São Paulo: Ed. Itatiaia/Ed. Da Universidade de São Paulo, 1981.

Miranda, Heloisa S., Mercedes M. C. Bustamante, and Antonio C. Miranda. "The Fire Factor." In The Cerrados of Brazil: Ecology and Natural History of a Neotropical Savanna, edited by Paulo S. Oliveira and Robert J. Marquis, 51-68. New York: Columbia University Press, 2002.

Morton, D. C., R. S. DeFries, Y. E. Shimabukuro, L. O. Anderson, E. Arai, F. del Bon Espirito-Santo, R. Freitas, and J. Morisette. "Cropland Expansion Changes Deforestation Dynamics in the Southern Brazilian Amazon." Proceedings of the National Academy of Sciences 103, no. 39 (September 26, 2006): 14637-41. https://doi.org/10.1073/pnas.0606377103.

Nehring, Ryan. "Yield of Dreams: Marching West and the Politics of Scientific Knowledge in the Brazilian Agricultural Research Corporation (Embrapa)." Geoforum 77 (December 2016): 206-17. https://doi.org/10.1016/j.geoforum.2016.11.006.

Oliveira, Paulo S., and Robert J. Marquis. "Introduction: Development of Research in the Cerrados." In The Cerrados of Brazil: Ecology and Natural History of a Neotropical Savanna, edited by Paulo Oliveira and Robert Marquis, 424. New York Chichester, West Sussex: Columbia University Press, 2002. https://doi.org/10.7312/oliv12042.

Pacheco, Fernando Estevão Rodrigues Crincoli, Fabricio de Andrade Caxito, Lucia Castanheira de Moraes, Yara Regina Marangoni, Roberto Paulo Zanon dos Santos, and Antonio Carlos Pedrosa-Soares. "Basaltic Ring Structures of the Serra Geral Formation at the Southern Triângulo Mineiro, Água Vermelha Region, Brazil." 
Journal of Volcanology and Geothermal Research 355 (April 2018): 136-48. https://doi.org/10.1016/j.jvolgeores.2017.06.019.

Paula, R. C., and K. DeMatteo. "Maned Wolf: Chrysocyon Brachyurus," 2015. https://doi.org/https://dx.doi.org/10.2305/IUCN.UK.20154.RLTS.T4819A82316878.en.

Peixoto, Josana de Castro, Bruno Junior Neves, Flávia Gonçalves Vasconcelos, Hamilton Barbosa Napolitano, Maria Gonçalves da Silva Barbalho, Sandro Dutra e Silva, and Lucimar Pinheiro Rosseto. "Flavonoids from Brazilian Cerrado: Biosynthesis, Chemical and Biological Profile." Molecules 24, no. 16 (August 9, 2019): 2891. https://doi.org/10.3390/molecules24162891.

Pohl, Johann Emanuel. Viagem No Interior Do Brasil. Belo Horizonte/São Paulo: Ed. Itatiaia/Ed. da Universidade de São Paulo, 1976.

Pyne, Stephen J. America's Fires: A Historical Context for Policy and Practice. Durham, North Carolina: Forest History Society, 2010.

---. Fire: A Brief History (Cycle of Fire). Seattle/London: University of Washington Press, 2001.

Queirolo, Diego, José Roberto Moreira, Lucía Soler, Louise H. Emmons, Flávio H.G. Rodrigues, Andrés A. Pautasso, José Luis Cartes, and Valéria Salvatori. "Historical and Current Range of the Near Threatened Maned Wolf Chrysocyon Brachyurus in South America." Oryx 45, no. 2 (April 4, 2011): 296-303. https://doi.org/10.1017/S0030605310000372.

Ratter, James A., Samuel Bridgewater, and J. Felipe Ribeiro. "Biodiversity Patterns of the Woody Vegetation of the Brazilian Cerrado." In Neotropical Savannas and Seasonally Dry Forests: Plant Diversity, Biogeography, and Conservation, edited by R. Toby Pennington and James A. Ratter, 31-66. Boca Raton: CRC Press, 2006. https://doi.org/10.1201/9781420004496-2.

Ratter, James A., H. de Freitas Leitão Filho, G. Argent, P. E. Gibbs, J. Semir, George Shepherd, and J. Tamashiro. "Floristic Composition and Community Structure of a Southern Cerrado Area in Brazil." Notes from the Royal Botanic Garden, Edinburgh 45, no. 1 (1988): 137-51.

Ratter, James A., J. Felipe Ribeiro, and Samuel Bridgewater. "The Brazilian Cerrado Vegetation and Threats to Its Biodiversity." Annals of Botany 80, no. 3 (1997): 22330. https://doi.org/10.1006/anbo.1997.0469.

Riedl-Dorn, Christa. Johann Natterer e a Missão Austríaca Para o Brasil. Petrópolis: Index, 1999.

Roubik, David W. Ecology and Natural History of Tropical Bees. Cambridge: Cambridge University Press, 1989. https://doi.org/10.1017/CBO9780511574641.

Saint-Hilaire, Auguste de. Viagem à Província de Goiás. Belo Horizonte/São Paulo: Ed. 
Itatiaia/Editora da Universidade de São Paulo, 1975.

Sano, Edson Eyji, Roberto Rosa, Jorge Luís Silva Brito, and Laerte Guimarães Ferreira. "Mapeamento de Cobertura Vegetal Do Bioma Cerrado: Estatísticas e Resultados." Planaltina (DF), 2007. https://www.infoteca.cnptia.embrapa.br/bitstream/doc/570887/1/doc190.pdf.

Santana, Carlos Augusto M., and José Rente Nascimento. "Public Policies and Agricultural Investment in Brazil (Final Report)." Brasília: Food and Agriculture Organization of the United Nations Policy Assistance Support Service (TCSP), 2012.

http://www.fao.org/fileadmin/templates/tci/pdf/InvestmentPolicy/Inv_in_B r_agriculture_-_20_08_2012.pdf.

Santos, Boaventura de Sousa. Pela Mão de Alice: O Social e o Político Na PósModernidade. São Paulo: Cortez, 2013.

Santos, Gilton Mendes dos, and Yasmine Antonini. "The Traditional Knowledge on Stingless Bees (Apidae: Meliponina) Used by the Enawene-Nawe Tribe in Western Brazil." Journal of Ethnobiology and Ethnomedicine 4, no. 19 (December 15, 2008): 1-9. https://doi.org/10.1186/1746-4269-4-19.

Silva, Claiton Márcio da. "A Face Infértil Do Brasil: Ciência, Recursos Hídricos e o Debate Sobre (in)Fertilidade Dos Solos Do Cerrado Brasileiro, 1892-1942." História, Ciências, Saúde-Manguinhos 26, no. 2 (April 2019): 483-500. https://doi.org/10.1590/s0104-59702019000200007.

Silva, Fernando Antônio Macena da, Eduardo Delgado Assad, Ercília Torres Steinke, and Artur Gustavo Müller. "Clima Do Bioma Cerrado." In Agricultura Tropical : Quatro Décadas de Inovações Tecnológicas, Institucionais e Políticas, edited by Ana Christina Sagebin Albuquerque and Aliomar Gabriel da Silva, 2:93-148. Brasília: Embrapa Informação Tecnológica, 2008.

Simon, Marcelo F., Rosaura Grether, Luciano P. de Queiroz, Cynthia Skema, R. Toby Pennington, and Colin E. Hughes. "Recent Assembly of the Cerrado, a Neotropical Plant Diversity Hotspot, by in Situ Evolution of Adaptations to Fire." Proceedings of the National Academy of Sciences 106, no. 48 (2009): 20359-64. https://doi.org/10.1073/pnas.0903410106.

Simon, Marcelo F., and R. Toby Pennington. "Evidence for Adaptation to Fire Regimes in the Tropical Savannas of the Brazilian Cerrado." International Journal of Plant Sciences 173, no. 6 (July 2012): 711-23. https://doi.org/10.1086/665973.

Spera, Stephanie. "Agricultural Intensification Can Preserve the Brazilian Cerrado: Applying Lessons From Mato Grosso and Goiás to Brazil's Last Agricultural Frontier." Tropical Conservation Science 10 (January 30, 2017): 1-7. https://doi.org/10.1177/1940082917720662.

Strassburg, Bernardo B. N., Thomas Brooks, Rafael Feltran-Barbieri, Alvaro Iribarrem, Renato Crouzeilles, Rafael Loyola, Agnieszka E. Latawiec, et al. "Moment of Truth 
for the Cerrado Hotspot." Nature Ecology E Evolution 1, no. 4 (April 23, 2017): 1-3. https://doi.org/10.1038/s41559-017-0099.

Torres, Pedro Sergio Urquijo. Humboldt y El Jorullo: Historia de Una Exploración. México: Secretaria de Medio Ambiente y Recursos Naturales/Instituto Nacional de Ecologia (INE-SEMARNAT)/Universidade Nacional Autónoma de México, 2017.

Venturieri, Giorgio Cristino. Criação de Abelhas Indígenas Sem Ferrão. 2nd ed. Belém: Embrapa Amazônia Oriental, 2008.

Vieira Filho, José Eustáquio Ribeiro. Expansão Da Fronteira Agrícola No Brasil: Desafios e Perspectivas. Brasília/Rio de Janeiro: Ipea (Instituto de Pesquisa Econômica Aplicada), 2016.

Waibel, Leo. "A Vegetação e o Uso Da Terra No Planalto Central." Revista Brasileira de Geografia 10, no. 3 (1948): 335-80.

---. "Vegetation and Land Use in the Planalto Central of Brazil." Geographical Review 38, no. 4 (October 1948): 529-54. https://doi.org/10.2307/211442.

Warming, Eugenius. "Descrição Da Natureza Do Brasil Tropical, Especialmente Do Campo." In A Canção Das Palmeiras: Eugenius Warming, Um Jovem Botânico No Brasil, edited by Maria do Carmo Andrade Gomes, 56. Belo Horizonte: Fundação João Pinheiro, 2006.

Wilcox, Robert W. Cattle in the Backlands: Mato Grosso and the Evolution of Ranching in the Brazilian Tropics. Austin: University of Texas Press, 2017.

Worster, Donald. Dust Bowl: The Southern Plains in the 1930s. New York: Oxford University Press, 1979.

---. "History as Natural History: An Essay on Theory and Method." Pacific Historical Review 53, no. 1 (February 1984): 1-19. https://doi.org/10.2307/3639376.

---. Nature's Economy: A History of Ecological Ideas. New York: Cambridge University Press, 1994.

---. Shrinking the Earth: The Rise and Decline of American Abundance. New York: OUP (USA), 2016.

---. "World without Borders: The Internationalizing of Environmental History." Environmental Review: ER 6, no. 2 (1982): 8-13. https://doi.org/10.2307/3984152.

Wulf, Andrea. The Invention of Nature: Alexander von Humboldt's New World. New York: Alfred A. Knoft, 2015. 


\section{Desafiar la Historia Ambiental del Cerrado: Ciencia, Biodiversidad y Política sobre la Frontera Agrícola Brasileña}

\section{RESUMEN}

Este artículo presenta un panorama de la historia ambiental del Cerrado brasileño, sus características ambientales y los procesos relacionados con el cambio histórico de los paisajes de este ecosistema amenazado. Acá se subraya las clasificaciones conflictivas en torno al Cerrado, el papel de la política en el establecimiento de aquellas y las consecuencias ambientales de tales clasificaciones. Se considera que más que sólo describir un ambiente, la clasificación de un ecosistema es un proceso político que involucra interacciones socioecológicas complejas. Las fuentes utilizadas permiten identificar los diferentes intentos por dar a conocer y "conquistar" el Cerrado, poniendo juntas las perspectivas interdisciplinarias de una variedad de actores e instituciones. Los desafíos historiográficos van más allá de las descripciones ambientales que dicen que las interacciones socioecológicas que han moldeado este ecosistema único son igualmente complejas. Las conclusiones de este artículo refuerzan el papel interdisciplinario de la historia ambiental en el estudio de los ecosistemas y las complejas relaciones entre cultura y naturaleza.

Palabras Clave: Cerrado; Historia Ambiental; Frontera Agrícola. 